\title{
The States as a Laboratory: Legal Innovation and State Competition for Corporate Charters
}

\section{Roberta Romano ${ }^{\dagger}$}

Corporate law is an arena in which the metaphor of the "states as a laboratory" describes actual practice, and, for the most part, this is a laboratory that has worked reasonably well. The goal of this Article is to map out over time the diffusion of corporate law reforms across the states. The lawmaking pattern we observe indicates a dynamic process in which legal innovations originate from several sources, creating a period of legal experimentation that tends to identify a statutory formulation that is thereafter adopted by the vast majority of states. Delaware and the Model Act quite often work in tandem. But there are occasions when they advance differing legal rules, accounting for some of the diversity in corporation codes that we observe.

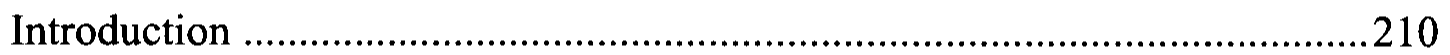

I. Key Features of U.S. Corporate Law ....................................................212

II. The Laboratory of State Competition for Charters …..............................214

A. The Diffusion of Corporate Law Reforms ........................................216

1. The Drive for Greater Organizational Flexibility and Delaware's 1967 Code Revision ..............................................216

2. The D \& O Insurance Crisis and Limitations on Directors'

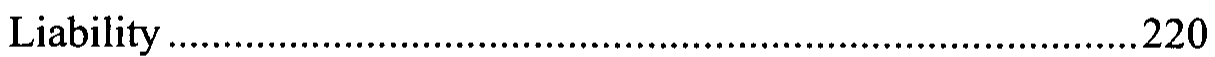

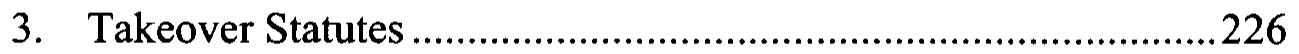

B. Role of the Model Business Corporation Act ....................................236

1. The Model Act and the 1967 Delaware Code Modernization.....238

2. The Model Act and 1980s Initiatives Limiting Director Liability and Regulating Takeovers ........................................239

III. Conclusion 246

\footnotetext{
† Oscar M. Ruebhausen Professor of Law, Yale Law School, Research Associate, National Bureau of Economic Research and Fellow, European Corporate Governance Institute. I would like to thank for helpful comments Alan Gerber, William Carney, Robert Daines, Marcel Kahan, Ehud Kamar, Jonathan Macey, Eric Patashnik, and participants in the Columbia Law School Contemporary Corporate Law Scholarship Reading Group, Florida State University College of Law Faculty Workshop, New York University Law School Law and Economics Workshop, and University of Pennsylvania ILE/Finance Seminar.
} 
Introduction

Corporate law, the legal rules governing relations between managers and shareholders of for-profit corporations, is an arena in which the advantage of our political system of federalism-encapsulated in the metaphor of the "states as a laboratory"-describes actual practice. For the most part, this is a laboratory that has worked reasonably well. The goal of this Article is to map out over time the product of this laboratory: the diffusion of corporate law reforms across the states. The law-making pattern we observe indicates a dynamic process in which legal innovations originate from several sources, creating a period of legal experimentation that tends to identify a principal statutory formulation that is thereafter adopted by a majority of states. It is difficult to imagine that such dynamism could be generated by the centralized lawmaking process that exists at the national level.

The development of corporate law has been left to the states with sporadic federal intervention: the New Deal laws regulating the issuance of securities, ${ }^{1}$ the terms of cash takeover bids, ${ }^{2}$ and most recently, audit committees and executive loans. ${ }^{3}$ Federalism has succeeded in this domain because the states have sorted out amongst themselves who has exclusive jurisdiction over corporate law to minimize conflict by adopting an "internal affairs" jurisdictional rule in which the governing choice of law rule is the corporation's statutory domicile. This contrasts with other potential conflict rules, such as physical domicile (the corporate law conflicts rule in most of continental Europe) or the domicile of the buyer or seller of a firm's securities (U.S. states' securities law conflicts rule). The latter conflicts rule would subject firms operating across state lines to multiple legal regimes in the absence of federal regulation.

Accordingly, U.S. corporations can select the legal regime for shareholder-manager relations from among the fifty states and the District of Columbia by their choice of incorporation state without having to establish any physical connection to the choice and without being exposed to extraterritorial restraints on organizational choices. A firm's statutory domicile is established by a simple paper filing with the chosen domicile's Secretary of State and is retained by maintaining a surrogate presence through a designated agent for the service of process, typically the lawyer or firm handling the incorporation documents.

The states' agreement on the internal affairs jurisdictional rule has had important consequences for the development of corporate law. The ease of

1 Securities Act of 1933, 15 U.S.C. $\S \S 77 a-77$ aa (1999); Securities Exchange Act of 1934, 15 U.S.C. $\S \S 78 \mathrm{a}-78111(2000)$.

2 The Williams Act of 1968 amends the Securities Exchange Act of 1934 and is codified at 15 U.S.C. § 78n(d), (e) (1999).

3 Sarbanes-Oxley Act of 2002, 15 U.S.C. $\$ 7201$ (2000). 
selecting a domicile whose exclusive jurisdiction is legally recognized has resulted in considerable experimentation and innovation in corporate law, as states have sought to retain locally-domiciled firms by offering up-to-date codes to meet changing business conditions. The output of this competition has been, for the most part, welfare-enhancing. This contention may be best illustrated by the fact that consumers of corporate law-investors, managers, and their lobbying organizations-have not advocated replacing the states' authority with either the federal government, or purely private contracts and self-regulating organizations, despite some academic support for both of those alternatives. ${ }^{4}$ In this regard, the production of corporate law stands as an exemplar of the advantage of a federal system: State competition for incorporations has spurred an innovative legal process that is responsive to a rapidly changing business environment to the benefit of firms and their investors.

After providing the context with a brief sketch of the key features of U.S. corporate law, this Article tracks the diffusion of the principal corporate law innovations of the past thirty years across the states: provisions increasing organizational flexibility introduced in the modernization of corporation codes in the late 1960s and limits on director liability and takeover regulation adopted in the 1980s. Although the speed of diffusion appears to vary positively with the intensity of managerial self-interest in the rule change, there is a persistent pattern. After some experimentation, a majority of states hone in on a specific statutory formulation to solve the problem at hand, and over time, the result is substantial uniformity across the states. The Article concludes by examining the interaction of Delaware and the Model Act in the legal innovative process, and the diffusion of provisions enhancing voting flexibility in the 1990s. For the most part, the two work in tandem, with Delaware's innovations being transmitted across other states through their replication in the Model Act. But on occasion the interaction exemplifies the advantages of the laboratory of the states: Where Model Act provisions are not adopted by a preponderance of the states, there is typically a very different provision in the Delaware code, which other states are following, and when the Model Act has repealed provisions that

4 E.g., Lucian A. Bebchuk, Federalism and the Corporation: The Desirable Limits on State Competition in Corporate Law, 105 HARV. L. REV. 1435 (1992) (federal regulation); William Cary, Federalism and Corporate Law: Reflections on Delaware, 83 YALE L. J. 663 (1974) (same); Paul G. Mahoney, The Exchange as Regulator, 83 VA. L. REV. 1453 (1997) (regulation by exchanges); Adam S. Pritchard, Markets As Monitors: A Proposal To Replace Class Actions with Exchanges as Securities Fraud Enforcers, 85 VA. L. REV. 925 (1999) (same); Gillian Hadfield \& Eric L. Tally, On Public Versus Private Provision of Corporate Law (USC Law and Econ. Res. Paper No. 4-18, and USC CLEO Research Paper No. C04-13, 2004), available at http://ssm.com/abstract $=570641$ (private contract approach). For a review of the empirical literature on state charter competition, which suggests that, for the most part, state competition benefits shareholders, see Sanjai Bhagat \& Roberta Romano, Empirical Studies of Corporate Law, in HANDBOOK OF LAW AND ECONOMICS (A. Mitchell Polinsky \& Steven Shavell, eds. forthcoming 2006), available at http://papers.ssm.com/sol3/papers.cfm?abstract_id= 728103. 
have not caught on with other states, it turns out that those provisions were absent from the Delaware statute.

\section{Key Features of U.S. Corporate Law}

Three key features that form the backbone of U.S. corporate law provide the context for evaluating the pattern of corporation law innovation that is the subject of this Article. First, U.S. corporate law is premised on shareholders being the parties in whose interest firms are to be managed. Second, state corporate law is for the most part enabling, in contrast to the federal securities laws, which are mandatory in application. Corporation codes consist of default rules that supply standard contract terms for corporate governance where the parties fail to specify alternative arrangements. These defaults can be customized to meet specific organizational requirements, such as increasing the votes required above the statutory default to a supermajority for a firm with a block-holder who wants to retain veto control. Third and perhaps most important, one state has dominated the market for incorporations of public firms for almost a century. About half of the largest corporations are incorporated in Delaware, the majority of firms going public for the first time are incorporated in Delaware, and the overwhelming majority of firms that change their domicile mid-stream reincorporate in Delaware. ${ }^{5}$

It is not fortuitous that the dominant incorporation state is a small state by nearly all measures. Because a corporate charter is a relational contract-it binds the state and firm in a multi-period relationship in which performance under the contract is not simultaneous - a state needs a mechanism by which it can commit to firms that it will maintain its code and otherwise not undo existing rules to firms' disadvantage. Without such a commitment, firms will not pay more than minimal incorporation fees. Delaware's success in the chartering market has provided it with just such a commitment device. A substantial portion of Delaware's tax revenue-an average of $17 \%$ over the past several decades - is derived from incorporation fees. ${ }^{6}$ Moreover, as a small state with limited indigenous revenue sources, there is no ready substitute to which Delaware can turn to maintain the level of services it provides its citizens in the absence of a vigorous incorporation business. This financial dependency on incorporation fees makes Delaware highly responsive to the requirements of corporations for an updated legal regime; it cannot afford to

5 E.g., Curtis Alva, Delaware and the Market for Corporate Charters: History and Agency, 15 DEL. J. CORP. L. 885, 887 (1990) (largest firms); Robert Daines, Does Delaware Law Improve Firm Value?, 62 J. FIN. ECON. 525, 538 (2001) (NYSE firms); Robert Daines, The Incorporation Choices of IPO Firms, 77 N.Y.U. L. REV. 1559, 1571 (2002) (IPO firms); Roberta Romano, Law as a Product: Some Pieces of the Incorporation Puzzle, 1 J.L. ECON. \& ORG. 225, 244 (1985) (reincorporating firms and largest firms).

6 Roberta Romano, The AdVANTAge of COMPETITIVE FEdERALiSM For SeCurities REGULATION 131-32 (2002). 
lose domestic corporations from being slow to update its code. Because it would lose a major revenue source if the number of domestic incorporations markedly declined, Delaware is a hostage to its own success, which makes credible a commitment to corporate law responsiveness. Aware of this situation, firms select it as their domicile in droves. ${ }^{7}$

In addition to a reputation for responsiveness created by dependence on franchise fee revenues, Delaware has made a substantial investment in assets that have no alternative use at any comparable value besides the corporate chartering business. Such assets can be characterized as relation-specific legal capital - that is, legal capital specific to the corporate chartering relation. Those assets are a comprehensive body of corporate case law and judicial expertise in administering corporate law, ${ }^{8}$ assisted by administrative expertise in expedited processing of corporate filings. Because the value of its investment in those assets would be diminished if it were to lose out to another state in the chartering market, Delaware has an incentive to be responsive to firms' legal needs. Thus, Delaware's legal capital functions as an additional credible commitment device.

The fact that many firms are incorporated in Delaware interacts with those assets to solidify Delaware's advantage over other states in attracting further incorporations. The more firms incorporated in the state, the more transactions will be undertaken and hence the more likely a legal precedent will be established for any particular transaction, providing greater certainty for future transactors. In addition, the more incorporations there are, the more the state relies on the franchise revenues and the more responsive it is in updating legislation. Yet both of those behavioral responses-more statutory responsiveness and more legal precedents-will lead more firms to find Delaware appealing and to relocate there. How can states with a small number of local businesses mitigate their disadvantage as a domicile of being unable to offer a store of legal precedents and, therefore, of providing less legal certainty, compared to a Delaware domicile? The American Bar Association's Model Business Corporation Act provides a legislative template for such states ${ }^{9}$ through which they can expand the stock of precedents. By drawing statutory language from the Model Act, a state can expand the set of precedents applicable to locally incorporated firms to include legal outcomes from other

7 This analysis was introduced in Romano, supra note 5, and relies on Oliver Williamson's work on transaction-specific assets. E.g., Oliver E. Williamson, Credible Commitments: Using Hostages To Support Exchange, 73 AM. ECON. REV. 519 (1983).

8 There is a specialized trial court, the Chancery court, that hears all corporate law cases, and possession of expertise in corporate law is considered in the appointment process for Supreme Court justices, in contrast to other states.

9 Section II.B, infra, discusses the creation and revision of the Model Act, and its role in the diffusion of statutory innovations across the states. 
Model Act states. At present, thirty-two states and the District of Columbia have adopted the Model Act, but most large states have not. ${ }^{10}$

\section{The Laboratory of State Competition for Charters}

Despite Delaware's overwhelming dominance in the chartering market, there is evidence that states enact legal reforms to maintain their level of local incorporations, putting them in competition with Delaware. That is why this is an area for which the metaphor of "the states as a laboratory" is apt. Three principal indicia of state competition have been noted in the corporate law literature. First, corporate law innovations diffuse across states in an S-shaped (ogive) curve (the proportion of adopters increases with time), a pattern that is interpreted in the economic literature as a sign of competition. ${ }^{11}$ Second, state franchise revenues are significantly positively related to the responsiveness of a state's corporate legal system to firm demands, and the effect remains even if Delaware is excluded from the analysis. ${ }^{12}$ Finally, firms migrate from states with low levels of responsiveness to those with higher levels. ${ }^{13}$

This Article focuses on the first facet of competition, the diffusion of legal innovation, which is the dimension of charter competition that is most closely related to the idea of the states as a laboratory of democracy. The diffusion pattern suggests that states can be characterized as if they were searching for the most suitable corporation laws in a changing business environment, so as to induce firms to incorporate locally. The modus operandi for the states' activity is most typically corporate lawyers acting in their self-interest and not government officials. ${ }^{14}$ That is, given Delaware's leading position, other states are engaged in what can be best described as a form of "defensive" competition, in which the local bar advocates law reform so as to be able to offer a local domicile choice to their clients. This Article will not discuss the other two indicia of competition, although all three features are interrelated: Namely, after Delaware, states that are early to adopt corporate law innovations are more likely to succeed in the chartering market by retaining more locallydomiciled firms.

10 The list of states identified as adopting the Model Act by its drafters can be found in MOdEl BUS. CORP. ACT ANN. intro. at xxvii (2005).

11 Romano, supra note 5, at 233-35; William J. Carney, Federalism and Corporate Law: A Non-Delaware View of the Results of Competition, in INTERNATIONAL REGULATORY COMPETITION AND COORDINATION 153-83 (William W. Bratton et al. eds., 1996).

12 Romano, supra note 5, at 236-41. Note that responsiveness is measured as a function of the rate and extent to which legal innovations considered desirable by reincorporating firms are enacted.

13 Id. at 246-47; G. Moodie, Forty Years of Charter Competition: A Race To Protect Directors' from Liability? (Harvard Law Sch. John M. Olin Ctr. for Law, Econ., and Bus. Fellows' Discussion Paper No. 1, 2004). Moodie uses a similar measure to Romano's measure, supra note 5, of responsiveness: how quickly a state adopts an innovation.

14 Roberta Romano, Is Regulatory Competition a Problem or Irrelevant for Corporate Governance?, 21 OXFORD ECON. REV. 212, $218-21$ (2005). 
Table 1: Diffusion of Selected Corporate Law Statutes

\begin{tabular}{|c|c|c|c|}
\hline Statute & No. States & $\begin{array}{c}\text { First } \\
\text { adoption }\end{array}$ & $\begin{array}{c}\text { Interval } \\
\text { (years) }\end{array}$ \\
\hline Indemnification & 42 & 1961 & 20 \\
\hline Merger vote exemption & 22 & 1963 & 18 \\
\hline Appraisal exemption & 26 & 1967 & 14 \\
\hline Action by majority without meeting ${ }^{a}$ & 11 & 1949 & 26 \\
\hline Cumulative voting & 30 & 1892 & 89 \\
\hline Staggered board & 45 & 1887 & 94 \\
\hline Limited liability charter amendment & 46 & 1986 & 16 \\
\hline $1^{\text {st }}$ generation takeover statute & 37 & 1968 & 13 \\
\hline $2^{\text {nd }}$ generation takeover statute ${ }^{b}$ & 43 & 1982 & 17 \\
\hline Fair price ${ }^{c}$ & 27 & 1983 & 8 \\
\hline Control share acquisition & 27 & 1982 & 8 \\
\hline Business combination freeze ${ }^{c}$ & 33 & 1985 & 12 \\
\hline Other constituency $^{d}$ & 31 & 1983 & 16 \\
\hline Redemption rights & 3 & 1983 & 7 \\
\hline Poison pill validation & 28 & 1986 & 15 \\
\hline
\end{tabular}

a This count is as of 1975 , compared to 1981 for the other initiatives related to the modernization of corporation codes in the late 1960s.

b This row tallies the number of states with any second-generation statute.

${ }^{c}$ Of the twenty-seven fair price provisions, thirteen were enacted as part of the requirements of a business combination freeze statute. The table treats these thirteen statutes as separate fair price statutes, as well as separate business combination freeze statutes because that has been the approach taken in the literature counting up takeover statutes by state, e.g., Lucian Arye Bebchuk \& Alma Cohen, Firms' Decisions Where To Incorporate, 46 J.L. \& ECON. 383, 407 (2003); Guhan Subramanian, The Influence of Antitakeover Statutes on Incorporation Choice: Evidence on the 'Race' Debate and Antitakeover Overreaching, 150 U. PA. L. REV. 1795, 1828 (2002), although, in my view, that is inappropriate double-counting of the statutes. It should be noted that the yearly statute totals in this Article are not identical to those in the Subramanian study because I correct for several errors in that study's identification of enactment years.

' This count does not include Virginia, which has a statute phrasing directors' discretion in terms of considering the "continued independence" of the corporation when determining what is in its best interest, rather than the interest of specific non-shareholder constituents, as is the phrasing of other states' statutes, and consequently, most articles do not include the Virginia statute in this category. See, e.g., Bebchuk \& Cohen, supra note c; Charles Hansen, Other Constituency Statutes: A Search for Perspective, 46 BUS. LAW. 1355 (1991); Subramanian, supra note c. 


\section{A. The Diffusion of Corporate Law Reforms}

In the diffusion process of corporation laws, variation often exists at the outset: Different states enact different statutes to solve a particular perceived problem. Eventually, one of the variations comes to dominate as the preferred solution and is enacted by the vast majority of states. To illustrate how the corporate law innovation process has operated, three sets of important initiatives will be examined: the "modernization" of corporation codes associated with the 1967 revision of Delaware's corporation code; the adoption of statutes limiting directors' liability in the late 1980s; and the adoption of statutes making hostile takeovers more difficult during the same time period.

\section{The Drive for Greater Organizational Flexibility and Delaware's 1967 Code Revision}

In 1967, Delaware undertook a major revision of its corporation code, which ushered in an era in which many firms reincorporated there from states that lagged behind in code-updating. ${ }^{15}$ A major feature of the revision was to enhance organizational flexibility, continuing the trend of the earliest statutory innovations in the late 19th century that relaxed strictures on capital structure and corporate combinations and had placed New Jersey at center stage in the corporate charter market. ${ }^{16}$ In an earlier publication, I traced the adoption of several of the important organizational innovations that appeared in Delaware's 1967 revision across the fifty states. The tracked provisions were selected from commentary on the code identifying the major improvements and from survey responses of firms that had changed domicile, which indicated what types of code provisions were of interest to reincorporating firms. These tended to be provisions that increased organizational flexibility, and in particular, provisions reducing the cost of acquisitions. ${ }^{17}$

Table 1 provides information on the diffusion across the states of six statutory innovations associated with modern statutes and the 1967 Delaware revision. ${ }^{18}$ The interval over which the spread of the provisions throughout the

15 See Romano, supra note 5.

16 For a description of New Jersey's corporate initiatives in the late 19th century, see Christopher Grandy, New Jersey Corporate Chartermongering, 1875-1929, 49 J. ECON. HIST. 677, 681 (1989).

17 The provisions identified in infra note 18 (numbered 2, 3, and 4), reduced the formalities and cash payouts required for acquisitions, reducing the cost and facilitating the structuring of such transactions, moves that increased organizational flexibility. In addition, the provisions on cumulative voting and board structure (numbered 5 and 6 in infra note 18), enhanced organizational flexibility by permitting changes in governing structures that simplified, and thereby reduced the cost of, running director elections.

18 These include three statutory innovations tracked in my prior article, Romano, supra note 5 , and three additional statutes that I tracked at that time but did not include in the study because the diffusion process for those laws began before the data for that article's statistical analysis were available: (1) the explicit elaboration of an indemnification standard for directors and officers; (2) the 
states was tracked-from the initial state's adoption of the provision through fourteen years after the Delaware code revision-ranges from fourteen to ninety-six years. Table 2 indicates where Delaware stood in the innovation process for each provision, and Figure 1 tracks the diffusion progress of the six statutes from the initial adoption through fourteen years after the Delaware code revision. Two facts are worth noting with regard to these data. First, Delaware is not always the pioneering innovator, but of the more recent innovations, when not first it has been second or third in adopting the initiative. Second, the innovations spread across the states gradually over time, as a few states followed the pioneers early on, but most states responded years later. The path of the diffusion of the statutes follows an S-shaped cumulative distribution, similar to other studies of legal innovation. ${ }^{19}$

Delaware's position, which is close to the top of the list as an innovator, in conjunction with the gradual diffusion of provisions, suggests a pattern of experimentation regarding corporate initiatives. More specifically, Delaware would appear, on occasion, to behave as if it waited until another state acted, in order to calibrate more precisely the preferred response to changing business conditions. Other states follow suit in a more languid fashion, responding after the innovators' legislation proves sufficiently successful to be actively sought by firms, whose demand for legislative revision is typically communicated by legal counsel. ${ }^{20}$

Of course, the fact that there has been innovation by the states in corporate law does not of itself demonstrate that a national regime would not innovate at a similar rate. William Carney offers some suggestive, relevant data on the issue.

elimination of acquirers' shareholders' vote in mergers involving a specified percentage of the corporation's stock; (3) the elimination for publicly-traded corporations of appraisal rights (the right to obtain cash, at a price determined by a court, rather than the merger consideration); (4) the right of shareholders, by a majority vote, to take action without a meeting; (5) the ability to stagger the board of directors into classes for election rather than elect the full board at the annual meeting; and (6) the ability to eliminate cumulative voting (a voting rule for directors that facilitates minority representation on the board by permitting shareholders to cumulate their votes on one candidate rather than spread them evenly across each seat up for election). In addition to data on these six statutory innovations, Tables 1 and 2 include data relating to statutes discussed later in this Article.

19 E.g., Virginia Gray, Innovation in the States: A Diffusion Study, 67 AM. PoL. SCI. REV. 1174 (1973) (education, social welfare, and civil rights); Sharon M. Oster \& John M. Quigley, Regulatory Barriers to the Diffusion of Innovation: Some Evidence from Building Codes, 8 BELL J. ECON. 361 (1977) (residential construction).

20 See, e.g., Alva, supra note 5, at 898-901, 903-16 (detailing the key role of the bar in Delaware legislative process, and its initiation of legal innovations in the 1980s); William J. Carney, The Production of Corporate Law, 71 S. CAL. L. REV. 715 (1998) (discussing role of corporate bar in other states, which author considers less active than the Delaware bar due to reduced incentives and collective action problems); Jonathan R. Macey \& Geoffrey P. Miller, Toward an Interest-group Theory of Delaware Corporate Law, 65 TEX. L. REV. 469 (1987) (emphasizing importance of corporate bar in influencing Delaware corporate law); Andrew G. T. Moore II, State Competition: Panel Response, 8 CARDOZO L. REV. 779, 780-81 (1987) (describing how Delaware legislative reform derives from proposals of the bar). 
Table 2: Delaware's Position in the Diffusion Process

\begin{tabular}{|c|c|c|c|}
\hline Statute & $\begin{array}{l}\text { Year DE } \\
\text { adopted }\end{array}$ & $\begin{array}{l}\text { DE's } \\
\text { Rank }\end{array}$ & Pioneering State \\
\hline Indemnification & 1967 & 3 & New York \\
\hline Merger vote exemption & 1967 & 2 & Ohio $^{a}$ \\
\hline Appraisal exemption & 1967 & 1 & Delaware \\
\hline $\begin{array}{l}\text { Action by majority without } \\
\text { meeting }\end{array}$ & 1967 & 2 & Nevada \\
\hline Cumulative voting & 1917 & 9 & New York \\
\hline Staggered board & 1898 & 4 & Pennsylvania \\
\hline $\begin{array}{l}\text { Limited liability charter } \\
\text { amendment }\end{array}$ & 1986 & 1 & Delaware \\
\hline $1^{\text {st }}$ generation takeover statute & 1976 & 13 & Virginia \\
\hline $2^{\text {nd }}$ generation takeover statute: & 1988 & 30 & Ohio \\
\hline Business combination freeze & & 10 & New York \\
\hline $\begin{array}{l}\text { Business combination freeze } \\
\text { with no fair price provision }\end{array}$ & & $4(1)$ & $\begin{array}{l}\text { Kentucky } \\
\text { (Delaware) }\end{array}$ \\
\hline \multicolumn{4}{|c|}{$\begin{array}{l}\text { a The first merger vote exemption statute had higher threshold (1/6th) than Delaware, whose } \\
\text { hold was adopted by most other states. } \\
{ }^{b} \text { Kentucky was the first state (1986) whose business combination freeze statute did not have a } \\
\text { price provision but Kentucky had already adopted a separate fair price statute two years earlier } \\
\text { 4). That is also true of the two other states (Washington and Wisconsin) enacting a business } \\
\text { bination freeze statute without a fair price provision before Delaware. Delaware was the first state } \\
\text { out a preexisting fair price statute to enact a business combination freeze statute without a fair price } \\
\text { irement. }\end{array}$} \\
\hline
\end{tabular}

Carney compared the substantive content of the eight European Union (EU) company law directives to U.S. state corporation codes. ${ }^{21}$ The EU-level directives are equivalent to a national regime, as they are rules adopted by the central administrative government that the member states must incorporate into their codes, the goal being corporate law harmonization across the nations of the European Union. Carney finds that of 131 provisions, the vast majority do not appear in any U.S. state code. ${ }^{22}$ Most of those provisions are either

$22 I d$. It is possible that the mandatory rules in place in the EU are appropriate for EU firms, which, in contrast to U.S. firms, tend to have more concentrated ownership structures, but that 
mandatory terms that have long been abandoned by U.S. states as they adjusted their codes to enhance organizational flexibility at the turn of the century, or provisions directed at protecting interests other than shareholders, also long gone from U.S. state codes. A few provisions concerning divisions, that is, sales of assets to two or more corporations, were never contained in U.S. codes, which do not distinguish asset sales by the number of buyers. That difference indicates that the greater inflexibility of EU corporate law is a general, not simply temporal, phenomenon.

Figure 1: Diffusion Process: Six Statutes associated with the 1967 Modernization of Delaware's Corporation Code

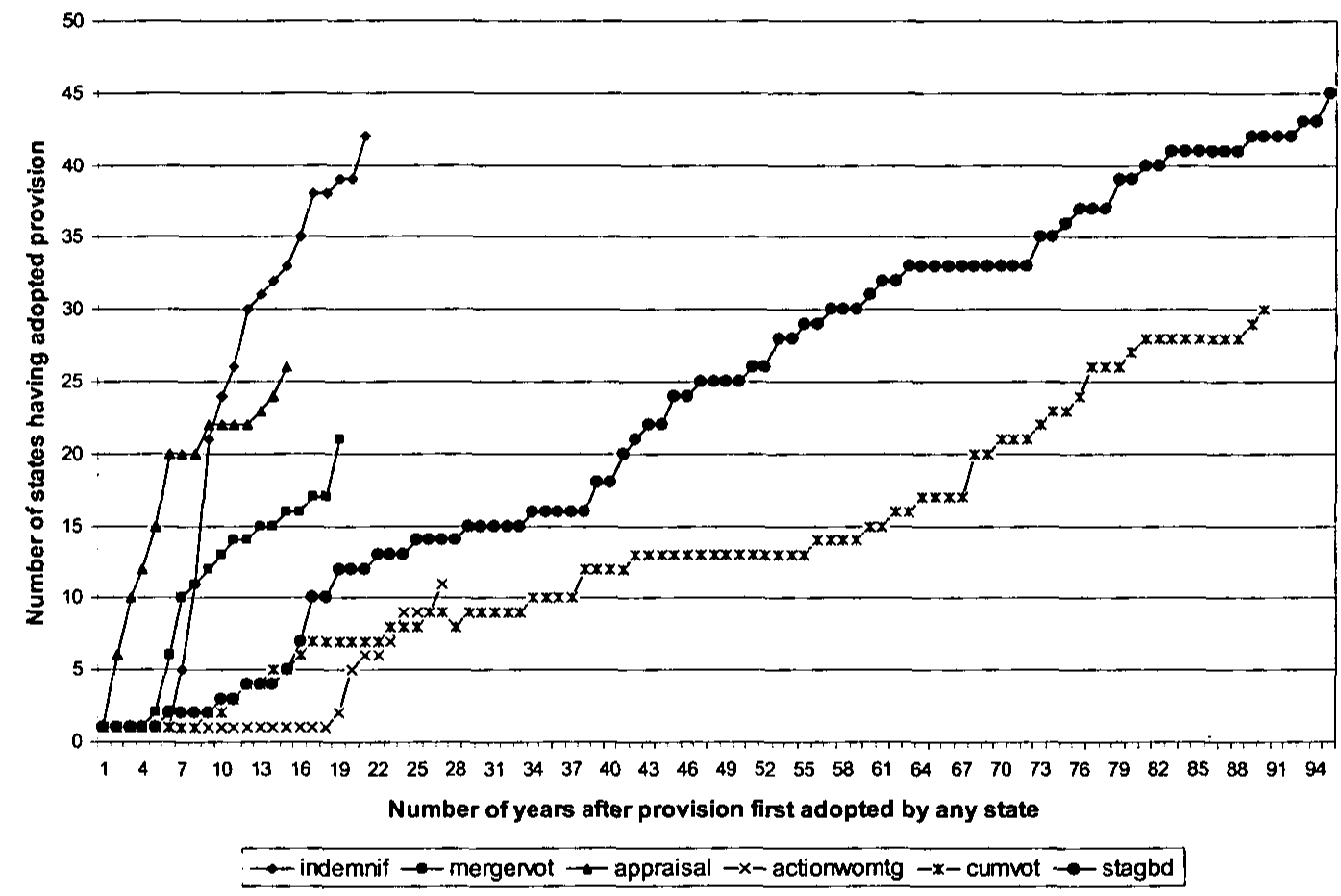

Indemnif = Indemnification clarification and expansion (42 states, first adoption 1961)

Mergervot $=$ Merger vote exemption (22 states, first adoption 1963)

Appraisal $=$ Appraisal rights exemption (26 states, first adoption 1967)

Actionwomtg = Action by majority without a meeting (11 states, first adoption 1949)

Cumvot $=$ Cumulative voting not required (30 states, first adoption 1892)

Stagbd $=$ Staggered board permitted (45 states, first adoption 1887)

Note: Last year tracked is 1981 for all statutes but actionwomtg, which is tracked through 1975

justification has not been advanced as the rationale for the rules that Carney examines (they are not, for example, rules involving the protection of minority shareholders). Moreover, the European Parliament recently approved the relaxation of some of the mandatory rules, such as preemptive rights, that Carney examined, which would not be expected under that hypothesis, as ownership structures have not significantly changed. See European Parliament Approves Proposal To Change Company Law To Ease Investment, 38 SEC. REG. \& L. REP (BNA). 477 (Mar. 20, 2006). 
While it is altogether possible that a U.S. centralized regime would not replicate the tendency of the EU directives to favor mandatory rules and organizational inflexibility that are at odds with the enabling focus of rules adopted in the laboratory of the states, it is more probable that a centralized regime would tend in that direction. Lending credence to this conjecture is the fact that the U.S. federal securities laws are closer to the corporate law approach of the EU than that of the states: They are mandatory rules that apply to all firms without permitting customization. Most important, where the SEC has sought to regulate matters of corporate governance, it has followed a mandatory rather than enabling approach. For example, the agency has used its authority over stock exchange rules to regulate corporate governance by "encouraging" exchanges to prescribe governance practices in listing requirements but refusing to approve rules that were not uniform across exchanges. This is done despite the fact that financial listing requirements give rise to differences in the sets of firms listed on particular exchanges, which suggest that firms' governance needs will also differ across exchanges. ${ }^{23}$

\section{The D \& O Insurance Crisis and Limitations on Directors' Liability}

The states' response to turbulence in the directors' and officers' liability insurance (D \& O insurance) market in the mid-1980s provides a more telling example of state-level experimentation and diffusion of innovation in reaction to changing business conditions and fleshes out the pattern in the 1967 statutory revision data. By 1984, the market for D \& O insurance had changed dramatically from the beginning of the decade: Firms seeking to renew policies or enter the market found premiums skyrocketing at the same time that coverage was shrinking and deductibles increasing. The tight insurance market continued into 1986. Many factors contributed to the market's turbulence, including the expansion of directors' liability. ${ }^{24}$ The most important case in this regard was a 1985 Delaware decision, Smith v. Van Gorkom, which held that outside directors had violated their duty of care when agreeing to a merger at a

23 See Roberta Romano, Foundations of CoRporate LaW 223 (1993) (voting listing requirements after federal court struck down direct regulation of voting); April Klein, Economic Determinants of Audit Committee Independence, 77 ACCT. REV. 435 (2002) (board and audit committee composition vary with firm characteristics); Stuart L. Gillan, Jay C. Hartzell, \& Laura T. Starks, Industries, Investment Opportunities, and Corporate Governance Structures (Univ. of Del. College of Bus. \& Econ. Ctr. for Corporate Governance, Working Paper No. 2002-003, 2003) (governance characteristics vary with industry); Roberta Romano, The Sarbanes-Oxley Act and the Making of Quack Corporate Governance 15 n.29, 40 n.82, 213 n.410 (Yale Int'l Center for Finance Working Paper No. 04-37, 2004) (board composition and committee structure listing requirements).

24 See Roberta Romano, What Went Wrong with Directors' and Officers' Liability Insurance?, 14 DEL. J. CORP. L. 1 (1989). 
substantial premium without sufficiently informing themselves of the firm's value. ${ }^{25}$

The disruption in insurance markets raised concerns that firms would have difficulty retaining quality outside directors, who many investors, particularly activist institutions, consider a key governance device in constraining managers to act in the shareholders' interest. This concern was magnified by the Van Gorkom decision. As a consequence, states sought to mitigate the perceived insurance crisis by limiting outside directors' liability for negligence. The idea was that lowering liability would relieve firms' potential problems in director recruitment created by inadequate or expensive $\mathrm{D} \& \mathrm{O}$ insurance.

By 1987, thirty-five states had modified their corporation codes to reduce directors' exposure to shareholder litigation and the $\mathrm{D} \& \mathrm{O}$ insurance market was beginning to stabilize. ${ }^{26}$ The story of how this came about is an excellent case study of the successful operation of federalism as a laboratory for legal reform. After early experimentation, most states settled on one solution: the one chosen by Delaware. In the first two years of legislative responses, three different approaches were implemented: reducing the standard of culpability, permitting charter amendments to limit or eliminate liability, and imposing statutory damage caps. ${ }^{27}$ But in a rapid diffusion process, the bulk of the states selected the limited liability charter amendment approach as the solution to their common problem.

The first state to respond to the insurance crisis was Indiana, which lowered the standard of care for directors from negligence to willful misconduct or recklessness in April $1986 .{ }^{28}$ By changing the statutory standard for a fiduciary breach, Indiana's solution to the insurance crisis applied automatically to all firms incorporated in the state. The Indiana solution was therefore self-executing. At the time, Delaware was considering how to respond to the $\mathrm{D} \& \mathrm{O}$ insurance market crisis and the Van Gorkom decision, and it chose not to follow Indiana's example. Instead of altering the standard of

25488 A. 2 d 858 (Del. 1985). It should be noted that Van Gorkom was decided after the D \& $\mathrm{O}$ crisis is thought to have begun, so it is best considered a contributing, rather than causal, factor for the market disruption.

26 Romano, supra note 24, at 30 \& nn.111-12 (1989) (citing statutes).

27 The classification of experimentation includes only completely new approaches to the problem that entailed limiting liability, as discussed in Romano, supra note 24 . It excludes other initiatives that were incremental to existing rules and the limit on liability derived from other constituency statutes (these provide boards with discretion to consider non-shareholder interests, sometimes explicitly limited to decisions regarding control changes; these statutes are discussed in the next section as they are more closely associated with takeover regulation than the D \& $O$ insurance crisis). For classification of all state responses see James J. Hanks, Jr., Evaluating Recent State Legislation on Director and Officer Liability Limitation and Indemnification, 43 BUS. LAW. 1207, 120910 (1988). These variations further indicate the experimentation and innovative processes of state competition, through which later adopters learn from the experience of pioneering states and refine the statutory formulation.

281986 Ind. Acts 1430 (codified at IND. CODE. ANN. §23-1-35-1(e) (Lexis 1999)). The statute became effective April 1, 1986. Leo Herzel \& Daniel Harris, Uninsured Boards Mount Weak Defense, NAT'L L.J., Apr. 21, 1986, at 19. 
culpability for all firms' directors, it left the decision up to individual firms' shareholders, authorizing the inclusion in corporate charters of provisions limiting or eliminating directors' personal liability for negligence. ${ }^{29}$ The Delaware approach has not differed much in practical effect from Indiana's, as the vast majority of firms have sought and obtained shareholder approval for a charter provision eliminating directors' liability for negligence. ${ }^{30}$

At the same time that the Indiana and Delaware legislatures were crafting their responses, the American Law Institute (ALI), was promoting a different alternative: a statutory limit on directors' liability that would be commensurate with their compensation. ${ }^{31}$ One state, Virginia, adopted the ALI approach a year after Indiana and Delaware acted, and capped damages at the greater of $\$ 100,000$ or the compensation the individual received from the corporation the year before the alleged misconduct. ${ }^{32}$ This third approach to the insurance crisis is procedurally self-executing like the Indiana approach, but substantively it is a limited version of Delaware's approach to the problem. Namely, a charter provision limiting directors' liability can be cast as a limitation on damages. In practice, the two approaches have not coincided, since firms have opted to eliminate directors' liability entirely rather than to cap it.

Although at the time of enactment, some commentators speculated that the Indiana statute would become the template for other states, ${ }^{33}$ the Delaware statute turned out to be the model. Twenty-nine of the first thirty-five states to enact a provision addressing the D \& O insurance crisis followed Delaware's lead and adopted a charter amendment provision. ${ }^{34}$ The second most popular approach, adopted by four states over the same time period, was Indiana's relaxation of the culpability standard. ${ }^{35}$ The ALI's damage cap solution never caught on, despite the prominence of many of the members of the organization in the legal profession. Within five years, Delaware's charter amendment solution to the perceived $\mathrm{D} \& \mathrm{O}$ insurance market crisis had been adopted by thirty-nine states, while the number following one of the other two approaches had risen only to six (and one of those states had also enacted the Delaware

2965 Del. Laws. 544 (1986), codified at DEL. CODE ANN. tit. 8, § 102(b)(7) (2001). The provision was enacted in June 1986 and became effective on July 1, 1986.

30 See, e.g., Michael Bradley \& Cindy A. Schipani, The Relevance of the Duty of Care Standard in Corporate Governance, 75 IOWA L. REV. 1, 62 (1989) (94\% of Delaware firms continuously trading on New York or American Stock Exchanges from 1982-86 adopted limited liability charter provisions).

31 See AM. LAW INST., PRINCIPLES OF CORPORATE GOVERNANCE: ANALYSIS AND RECOMMENDATIONS $\S 7.17$ (Tentative Draft No. 7, Apr. 10, 1987); AM. LaW INST., PrINCIPLES OF CORPORATE GOVERnANCE: ANALYSIS AND RECOMmEndations (Discussion Draft No. 1, June 3, 1985).

321987 Va. Acts 82 (codified at VA. CODE ANN. § 13.1-692.1 (1999)).

33 E.g., Herzel \& Harris, supra note 28 ("Indiana has just enacted a new corporation statute that may become a model for other states as well.").

34 Romano, supra note 24 , at 30.

35 Id. 
statute). ${ }^{36}$ Moreover, Virginia amended its statute to include a charter amendment provision, in addition to the statutory damages default provision. The inclusion in 1990 of the Delaware approach in the Model Business Corporation Act no doubt solidified the trend. ${ }^{37}$ Today, forty-six of fifty states have a limited liability charter provision; the other four have a relaxed culpability standard. The diffusion of initiatives to limit liability is summarized in Tables 1 and 2 and graphed in Figure 2.

Figure 2: Diffusion Process: Statutes Limiting Liability

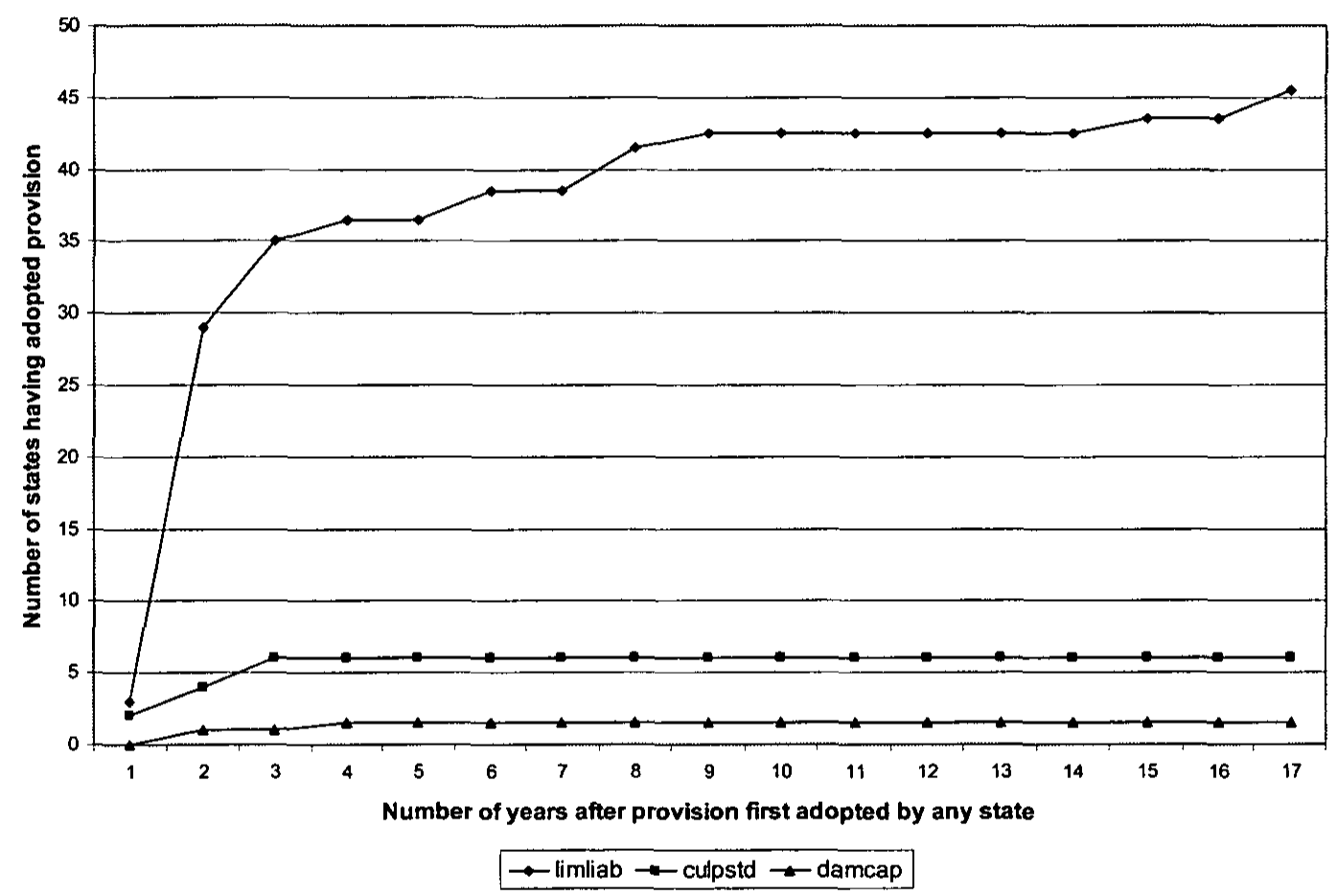

Limliab $=$ Limited liability charter amendment (45.5 states, first adoption 1986)

Culpstd = Relaxation of culpability standard (6 states, first adoption 1986)

Damcap = Damages cap (1.5 states, first adoption 1987)

Note: Connecticut statute permitting damages cap charter amendment allocated across two statutory types, as indicated in supra note 26.

The diffusion process of the limited liability statute, as evident in Figure 2, was far more rapid than those of the earlier innovations plotted in Figure 1.

36 Carney, supra note 11 , at 181 . The Connecticut statute is a hybrid of the Delaware and ALI approach: it permits firms to adopt charter amendments to limit directors' liability for damages to an amount not less than the compensation the individual received from the corporation during the year of the violation. CONN. GEN. STAT. ANN. $\S 33-636(b)(4)$ (West 2005). Figure 2 therefore counts it as onehalf limited liability charter amendment and one-half damages cap.

37 Comm. on Corp. Laws, Changes in the Revised Model Business Corporation ActAmendment Pertaining to the Liability of Directors, 45 BUS. LAW. 695 (1990). The impact of the Model Act on the diffusion process is discussed infra Section II.B. 
Using the same cut-off as applied to the diffusion of the 1967 Delaware reforms, forty-nine states had enacted one of the statutory forms of limitations on director liability within fourteen years of the first statutory formulation. The remaining state acted two years thereafter. Firms' demand for limiting directors' liability was, without question, the impetus for the rapid diffusion. Commentaries by practitioners in several states refer to concern that firms would reincorporate if the state did not adopt a limited liability statute similar to the Delaware provision. ${ }^{38}$ In addition, the perceived insurance crisis provided a reason for states to respond quickly to that concern, the easiest response being the selection of the leading incorporation state's tried solution.

Given that the Delaware statute offers the greatest flexibility of response, it is not altogether surprising that it came to dominate state choices. The Delaware approach, in contrast to that of Indiana, leaves the decision on liability to individual firms and investors, not legislators. This characteristic makes it appealing to investors, since their consent is required. Charter amendments limiting liability are uniformly approved by shareholders with the support of institutional investors, although those same investors often vigorously oppose other management initiatives, such as the adoption of takeover defenses. ${ }^{39}$ Such evidence strongly suggests that investors find the Delaware approach attractive. In addition, one study found significantly positive stock price reactions to the adoption of limited liability charter amendments by firms that had been performing poorly and arguably might be the most vulnerable to litigation. ${ }^{40}$ This is consistent with the view that for such firms, investors consider the provisions useful for attracting higher quality

38 E.g., Edgar F. Hansell et al., Director Liability Under Iowa Law-Duties and Protections, 13 J. CORP. L. 369, 392 (1988) ("The Iowa legislature, in part to avoid corporate flight from Iowa to reincorporate in Delaware and to take advantage of the new limited liability provisions, adopted legislation that became effective as of July 1, 1987, similar to that of Delaware."); Robert H. Roshe, New York's Response to the Director and Officer Liability Crisis: A Need To Reexamine the Importance of $D \& O$ Insurance, 54 BROOK. L. REV. 1305, 1318-19 n.81 (1989) ("The New York legislature was concerned that legislation was necessary to deter corporations from reincorporating into states which offered laws more favorable to the protectionist needs of directors and officers in light of the corporate liability crisis.") (citing N.Y. Governor's memorandum in support of proposed legislation in 1986 to adopt Delaware's statute beyond state's prior expansion of indemnification provisions); id. (quoting California lawyer as stating, in another journal article, "[s]ince July [of 1987], California corporations have been reincorporating in Delaware at a rapid pace. If the exodus of corporations from California continues, the legislature may consider amending the [California] Corporations Code to follow Delaware's lead"-which it did); Comment, S.D. CoDIfIED LAwS $\S$ 47-2-58.8 (2000) (repealed 2005 and recodified at 47-1A-202.1) ("The [South Dakota] provision contains the same exceptions as Delaware but also authorizes adoption of liability-limiting provisions for the benefit of directors of insurance companies (against policy holders), depository institutions (against depositors), and rural water systems (against members). This is an extraordinary departure from mainstream liability-limiting charter option statutes, and seems like a cynical display of charter-mongering.").

39 There is an extensive literature on the subjects of institutional investor activism which indicates that altering directors' limited liability has not been on their agenda. For a literature review, see Roberta Romano, Less is More: Making Institutional Investor Activism a Valuable Mechanism of Corporate Governance, 18 YALE J. ON REG. 174 (2001).

40 See Yaron Brook \& Ramesh K.S. Rao, Shareholder Wealth Effects of Directors' Liability Limitations Provisions, 29 J. FIN. \& QUANTITATIVE ANALYSIS 481 (1994). 
outside directors. It should further be noted that the success of the Delaware approach would not have been predicted by proponents of the view that state competition is a "race to the bottom," and that federalism produces laws that entrench managers and exploit shareholders. From that perspective, the selfexecuting Indiana approach ought to have predominated in the laboratory of state lawmaking because, in contrast to the Delaware statute, it offers directors absolution from liability for negligence immediately upon legislative action, without the need for firms to obtain their shareholders' consent.

There was even greater experimentation in handling limitations on director liability than would be suggested from the figure and tables, which track the adoption of provisions permitting charter limitations of liability without adjusting for nuances of differences in statutes. In modeling their legislation after the Delaware statute, several states further refined the provision by, for example, making the language more precise, eliminating the specific exception for breaches of the duty of loyalty, covering officers as well as directors, and applying the limitation to third-party litigation as well as shareholder actions. ${ }^{41}$

This active shaping of liability limits, producing variety amidst a rapid diffusion of an innovative solution to a common problem across the states, exemplifies the advantages of federalism. States engaged in efforts to identify and hone an appropriate response to the insurance crisis, and, in a relatively short time, came up with a response offering organizational flexibility and individualization. It is difficult to imagine as rapid a response to a problem in a centralized regime. To provide a straightforward comparison, the Delaware legislature's action, which reversed Smith v. Van Gorkom, occurred within a year and a half of the decision. Of Delaware code amendments whose legislative history indicates that they were enacted in response to Delaware court decisions, the median interval between legislative response and decision was two years, while the average was eight years. ${ }^{42}$ By contrast, the average

41 See Hanks, supra note 27, at 1211-15.

42 Memorandum from Amy Simmerman, Intern, Morris, Nichols, Arsht \& Tunnell, Amendments to the Delaware General Corporation Law (2005) (on file with author). I would like to thank John F. Johnston of the Morris, Nichols, Arsht \& Tunnell firm for generously undertaking to have such a list compiled for me, in response to communication among John, Bill Allen and myself regarding the relation between a recent code amendment and the decision in Black $v$. Hollinger International Inc., 872 A.2d 559 (2005). The list is underinclusive because not all responses to judicial decisions are identified in the legislative history. The limited liability statute, for example, is not on the list (although I have included it in the calculations in the text and this note). Ms. Simmerman's list began with the 1967 code modemization, because it is difficult to document earlier amendments, and identified twenty-eight amendments that were related to specific Delaware cases, including five provisions in the 1967 statute that were responses to decades-old decisions. Of twenty-nine amendments (the twenty-eight identified by Ms. Simmerman's research and the limited liability statute), $45 \%$ were enacted more than two years after the decision. It should further be noted that only somewhat more than one-third (eleven of twentynine) of the statutes appear to have been explicit reversals; the same number (eleven) were characterized as efforts to clarify issues left in confusion or rendered ambiguous, or to resolve questions raised, by court decisions. Examining solely the reversals, the median time to reversal was still two years, but the average reversal took eleven years; the average is closer to the data regarding Congress' reaction to 
interval for reversals of U.S. Supreme Court decisions involving statutory interpretation in the comprehensive study by William Eskridge of the 1967-90 Congresses was twelve years, with $68 \%$ of the reversals occurring more than two years after the decision. ${ }^{43}$

\section{Takeover Statutes}

There is even greater variation across state codes in the regulation of takeovers than there is in liability limitations. Two factors have contributed to the high degree of variation: Supreme Court jurisprudence and efforts to protect specific companies from unwanted bids. Tables 1 and 2 and Figures 3 and 4 depict the diffusion process of first- and second-generation takeover statutes. First-generation takeover statutes, which took the form of direct regulation of bids, are so-called because after they were invalidated by the Supreme Court in 1982 in Edgar v. MITE Corp., ${ }^{44}$ they were superseded by a subsequent generation of statutes. As Figure 3 shows, before the Supreme Court decision in $M I T E$, the statutory innovation of first-generation statutes moved quickly through the states in a neat $\mathrm{S}$-shaped fashion, and was adopted by thirty-seven states in thirteen years.

States did not abandon their regulatory efforts following the MITE decision. Instead, they reformulated their regulatory strategy to approximate more closely conventional corporate law rules, through regulation of shareholder voting and business combinations with hostile bidders. As corporate law was traditionally characterized as a domain left to the states in the allocation of federal authority, it was thought that takeover regulation framed along the lines of corporate code provisions would be less likely to be found objectionable by the Supreme Court than the original statutes, which had hewed rather closely to a securities regulation approach. Consistent with that strategy, most post-MITE "second-" or "third-generation" statutes are enabling in form, establishing a default rule from which firms can opt-out, in contrast to the mandatory first-generation statutes. Because shareholders receive large premiums in hostile takeovers whereas managers have a potential conflict of

Supreme Court decisions, see infra note 43 and accompanying text, but that comparison is misleading as a gauge of responsiveness, which is better measured by the median: Only $45 \%$ of the reversals occurred more than two years after the decision, and the bulk of those were the 1967 statutory changes.

43 William N. Eskridge, Jr., Overriding Supreme Court Statutory Interpretation Decisions, 101 YALE L.J., 331 (1991). None of the cases in the study involved the federal securities laws; but consistent with those data, in the Sarbanes-Oxley Act of 2002, Congress overturned a U.S. Supreme Court decision on the statute of limitations for securities violations that had been decided ten years earlier, Lampf v. Gilbertson, 501 U.S. 350 (1991).

44457 U.S. 624 (1982) (invalidating Illinois statute as a burden on interstate commerce due to its extraterritorial application). The first state takeover statute was adopted by Virginia in 1968, the same year the Williams Act, a federal statute regulating takeovers, was enacted, and the form was similar: delaying the success of a hostile bid by requiring bidders to register their offers with the government in advance. A plurality of the Supreme Court also considered the Illinois statute to be preempted by the Williams Act. 
interest - the loss of their positions upon a control change, many commentators consider such statutes, which are intended to reduce the success of a bid opposed by management, to favor managers at the shareholders' expense. ${ }^{45}$

\section{Figure 3: Diffusion Process: Takeover Statutes}

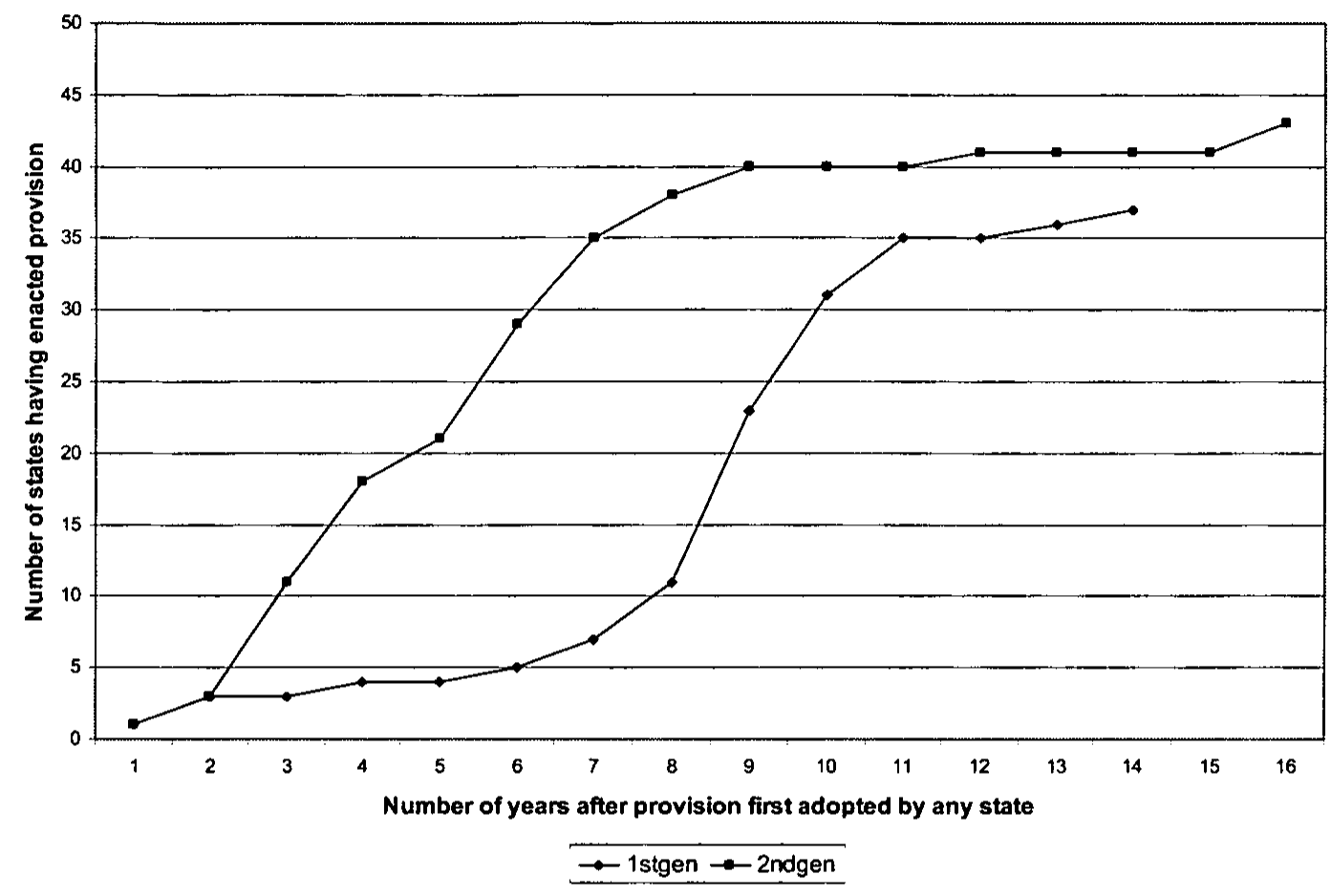

1 stgen $=$ First-generation takeover statute (37 states, first adoption 1968)

2ndgen $=$ Second-generation takeover statute (43 states, first adoption 1982)

The uncertainty regarding the constitutionality of state takeover regulation created by MITE led states to experiment with new regulation, as legal counsel differed in their assessments of what form of regulation would be found acceptable by courts. Ohio was the first state to act, enacting a takeover statute in November 1982, only a few months after MITE was decided. Its innovation, a "control share acquisition" statute, restricts an unwanted bidder's ability to vote shares acquired in a tender offer without the approval of a majority of the disinterested shareholders. ${ }^{46}$ Within a year of Ohio's new regulation, there were two other innovations: Maryland enacted a "fair price" statute, which fixes the

45 E.g., FRANK H. EASTERBRoOK \& DANiEL R. FiSCHEL, ECONOMIC STRUCTURE OF CORPORATE LAW 220-22 (1991). Takeover statutes and other defensive tactics might, however benefit shareholders by enhancing management's ability to negotiate a higher price which dispersed shareholders are not able to do. Moreover, a recent paper concludes that takeover statutes have had no effect on takeovers. See Marcel Kahan, The Demand for Corporate Law: Statutory Flexibility, Judicial Quality, or Takeover Protection? (N.Y. Univ. Law and Econ. Working Paper No. 04-017, 2004).

46 OHIO REV. CODE ANN. $§ 1701.83 .1$ (Lexis 2001). 
minimum price to be paid in the second phase of two-step acquisitions, ${ }^{47}$ and Pennsylvania adopted a "redemption rights" statute which requires any purchaser of a specified percentage of the shares of a company to acquire all of the remaining shares at the same price. ${ }^{48}$ At the same time, Pennsylvania adopted an "other constituency" statute, which permits directors to consider the interests of non-shareholders in business decisions. ${ }^{49}$ This statute received less attention among commentators as a template than the redemption rights provision, which is a variant of the fair price provision, because it seemed it would be less effective for defeating a bid. It did not alter bid terms or raise the bar regarding shareholder approval, and arguably was only a clarification rather than modification of the common law. ${ }^{50}$

Figures 3 and 4 plot the diffusion of second-generation takeover statutes. Figure 3 traces the diffusion across the states of the adoption of post-MITE takeover statutes. As Figure 3 shows, the diffusion of a second-generation statute occurred more rapidly than the first-generation statutes. Figure 4 breaks down the diffusion process of second- and third-generation statutes by statute type. As can be observed, the redemption rights innovation was a failure. It was adopted by only three other states, one of which later repealed it. In contrast, the fair price provision thrived, particularly in New York's 1985 permutation: a "business combination freeze" statute. This statute imposes a moratorium for a specified term of years before a successful unwanted bidder can engage in the transactions requiring a fair price under fair price statutes with the target company. After New York's innovative refinement, only two states enacted a fair price statute that was not also part of a business combination freeze statute, compared to twelve enacting the New York provision.

Some business combination freeze statutes do not, however, contain a fair price provision governing post-moratorium transactions. This was an innovation introduced by Delaware in 1988. Before Delaware's legislation, business combination freeze statutes were adopted without a fair price provision only when the enacting state already had a fair price statute on the books, which rendered superfluous including a fair price component in the business combination freeze law. To isolate the pattern of innovation in joining the fair price and business combination freeze statutory approaches, Figure 4 separately tracks the three statutory forms: New York-type statutes that have a fair price component; Delaware-type business combination freeze statutes that

47 MD. CODE ANN., CORPS. \& ASS'NS §§ 3-601 to 3-603 (West 1999).

481983 Pa. Laws 395 (codified at 15 PA STAT. ANN. § 1910, recodified and amended, 15 PA. STAT. ANN. § 2544 and ff (1995).

49 PA. CONS. STAT. ANN. $\S 515$ (West 1995).

50 See Charles Hansen, Other Constituency Statutes: A Search for Perspective, 46 BUS. LAW. 1355, 1357 (1991) (quoting Pennsylvania legislative history as intending to codify other state court decisions permitting consideration of nonshareholder interests). Some commentators also considered the statute to be a response to the D \& O insurance crisis, rather than hostile takeovers. See Hanks, supra note 27 . 
have no fair price component; and business combination freeze statutes adopted without a fair price provision because the enacting state already had a fair price statute. $^{51}$

\section{Figure 4: Diffusion Process: Second-Generation Takeover Statutes}

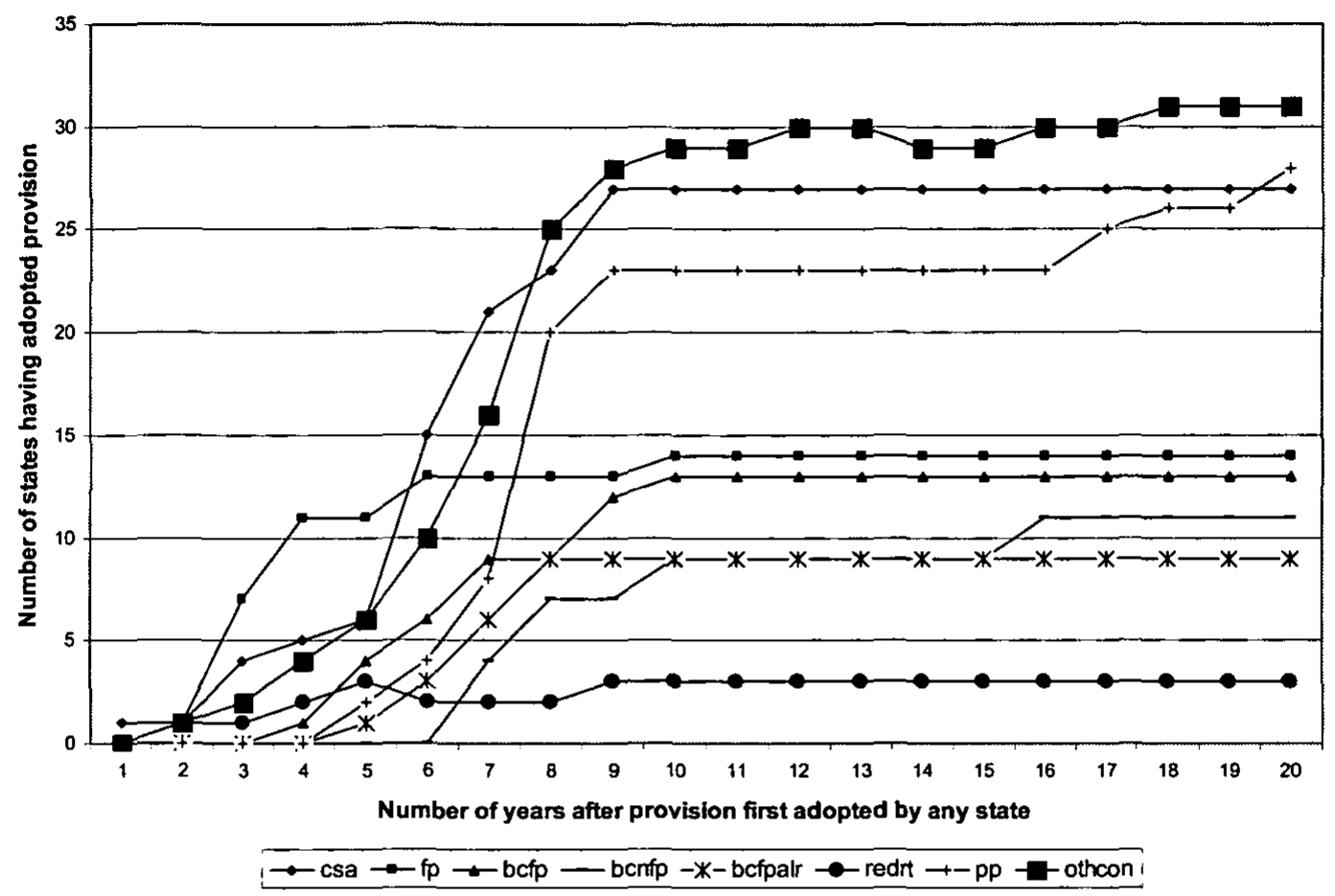

csa $=$ Control share acquisition statute (27 states, first adoption 1982)

$\mathrm{fp}=$ Fair price statute (14 states, first adoption 1983)

bcfp = Business combination freeze with fair price provision (13 states, first adoption 1985)

bcnfp = Business combination freeze with no fair price provision (11 states, first adoption 1988)

bcfpalr $=$ Business combination freeze in state with preexisting fair price provision ( 9 states, first adoption 1986)

othcon $=$ Other constituency statute (31 states, first adoption 1983)

redrt $=$ Redemption rights (3 states, first adoption 1983)

$\mathrm{pp}=$ Poison pill validation (28 states, first adoption 1986)

Note: CTS decision (1987) is year 6; enactment of business combination freeze with no fair price provision by Delaware (1988) is year 7.

The influence of the Supreme Court on the statutory variation is apparent in Figure 4: The diffusion pattern exhibits a take-off in adoption and a winnowing of experimentation after 1987, the year in which the Supreme Court

51 The last category also includes states that adopted a business combination freeze statute with a fair price provision while simultaneously eliminating an independent fair price statute that had been previously adopted. 
upheld the constitutionality of Indiana's control share acquisition statute in CTS Corp. v. Dynamics Corp. of America. ${ }^{52}$ The largest number of adoptions in 1987 also took the form of the Indiana statute, as legislatures followed the regulatory recipe approved by the Court. ${ }^{53}$ The number of states adopting the control share acquisition statute continued to increase in the years immediately following CTS as well (twenty-one of twenty-seven such statutes were enacted between May 1987 and 1989). Over time, however, business combination freeze and other constituency statutes came to be adopted more widely than the control share acquisition statute.

The Supreme Court decision upholding the Indiana statute, in sum, led to an explosion in legislative activity on takeovers as states perceived that there was a constitutionally acceptable solution to their concerns. They initially focused on the regulatory strategy that had been explicitly approved by the Supreme Court. Lower level courts reviewing other states' control share acquisition and business combination freeze statutes followed the Supreme Court's lead, as legislatures undoubtedly anticipated, and upheld the parallel statutes. The one exception was for provisions with extraterritorial reach. Such provisions retained what the Court held to be a critical flaw in the firstgeneration statute struck down in MITE, and were invalidated. ${ }^{54}$ These decisions encouraged interest groups and corporate management to lobby for legislation in states that had not yet responded with a second-generation statute. The diffusion process of takeover innovations throughout the period of constitutional uncertainty and its resolution was not a random process. States were consciously learning, copying, and refining each other's statutes. ${ }^{55}$ Members of the corporate bar and managers of the corporations they represented were intensely interested and involved in the legislative process. ${ }^{56}$

The second principal source of variation in second-generation takeover statutes is the firm-specific feature of much of the legislation. Statutes were often enacted to assist an in-state target in deterring an unwanted bid. ${ }^{57}$

52481 U.S. 69 (1987).

53 Legislators frequently stated for the legislative record in 1987 that they were copying the Indiana statute because its constitutionality had been upheld by the Supreme Court. See, e.g., Russell D. Garrett, Third-Generation Anti-Takeover Statutes in Oregon and Indiana After Dynamics: Target Corporations Control the Ship and Raiders Are Foiled, 24 WILLAMETTE L. REV. 73, 89 (1988).

54 Compare Amanda Acquisition Corp. v. Universal Foods Corp., 877 F.2d 496 (7th Cir. 1989) (upholding Wisconsin's business combination freeze statute), with Tyson Foods, Inc. v. McReynolds, 865 F.2d 99 (6th Cir. 1989) (invalidating Tennessee's control share and business combination freeze statutes to the extent they applied to a corporation headquartered in Tennessee but incorporated in Delaware).

55 E.g., GA. CODE ANN. $\S 14-2-232 \mathrm{cmt}$. (West 2006) (Georgia fair price provision compared to numerous states); OHIO REV. CODE ANN.§ $1704 \mathrm{cmt}$. (West 2001) (Ohio business combination freeze statute compared to Wisconsin statute); Garrett, supra note 53 (Oregon control share acquisition statute compared to Indiana statute). $111(1987)$

56 See, e.g., Roberta Romano, The Political Economy of Takeover Statutes, 73 VA. L. REV.

57 For lists matching targets with statutes, see Henry N. Butler, Corporation-Specific Antitakeover Statutes and the Market for Corporate Charters, 1988 WIS. L. REV. 365; Carney, supra note 
Pennsylvania's redemption rights innovation, for instance, was adopted to aid the Scott Paper Corporation in preventing a hostile takeover by a nonmanagement shareholder, Brascan Ltd. Brascan, a Canadian company, was trying to increase its $23.7 \%$ holdings in Scott Paper, and neither a fair price provision along the lines of Maryland's innovation, nor Indiana's control share acquisition statute, would have protected the target corporation as effectively as the redemption rights provision did. ${ }^{58}$ Firm-specific takeover statutes also help to explain why some states adopted multiple second-generation takeover statutes. For instance, several years after its adoption of the redemption rights provision that was targeted to assist Scott Paper, Pennsylvania adopted a control share acquisition and a business freeze statute ${ }^{59}$ Further legislation was, no doubt, considered necessary because the redemption rights provision was of little value for protecting targets whose unwanted bidders' offers were for $100 \%$ of the shares; such bids were unaffected, hence undeterred, by that statute. One other aspect of the firm-specificity of takeover statutes should be noted in order to grasp better the dynamics of legislation in this context. Hostile takeovers implicated one interest group not otherwise active in lobbying on corporation statutes: labor unions. Unions typically sought legislation restricting bids because they believed successful out-of-state bidders would eliminate local jobs. Management of a unionized firm therefore often found an important ally to influence lawmakers in this context. Union support might sway legislators concerned about local employment levels to enact a protective statute, especially when confronted with a concrete set of potential victims in the case of a specific bid, despite an absence of systematic empirical evidence that hostile takeovers result in production-level job losses.

Both the five-year interval between MITE and CTS and legislatures' desire to protect specific targets help to explain the considerable diversity in takeover statutes that is lacking in other corporate law contexts. There is, however, another key difference in the diffusion process of takeover statutes compared to other corporate laws. In contrast to the statutes earlier discussed, Delaware has not been at the forefront as a pioneering innovator in takeover regulation. Rather, it has been a laggard. Given its usual responsiveness to changing business conditions, it was slow to adopt a first-generation statute. It acted eight years after Virginia's innovation, making it the thirteenth state to respond to the uptake in hostile bids in the late 1960s and early 1970s. And it was even slower-the thirtieth state- to enact a second-generation statute post-MITE.

Moreover, Delaware's business combination freeze statute was less restrictive on several dimensions than the predecessor states' statutes, as was also true of its first-generation statute. There are a number of reasons for

20, at 750-51; Roberta Romano, The Future of Hostile Takeovers: Legislation and Public Opinion, 57 U. CIN. L. REV. 457 (1988); Romano, supra note 56, at 137-38.

58 Romano, supra note 56, at 137 n.66.

59 PA. CONS. STAT. ANN. §§ 2551-56, 2561-68 (West 1995). 
Delaware's more accommodating approach to hostile takeovers, which I have discussed in detail elsewhere, ${ }^{60}$ but one bears repeating here: Firm-specific takeover legislation does not have a dominant role in Delaware's political process as occurs in other states. As a statutory domicile, local job loss is not an overriding issue, and no one firm is therefore able to dictate the form or timing of legislation. ${ }^{61}$

Despite its relative position as a laggard, Delaware's role as an innovator whom other states copy is not completely inconsequential even in the takeover setting. Delaware's second-generation statute is less restrictive of hostile bidders on several dimensions, such as its lack of fair price restrictions, its shorter moratorium of three years, compared to New York's five-year freeze, ${ }^{62}$ and its innovative exemption of hostile bidders who acquire $85 \%$ of the shares. ${ }^{63}$ These features appear to have influenced other states' legislation. Figures 4 and 5 indicate that of business combination freeze statutes enacted after the Delaware legislation, a majority of states followed Delaware's threeyear rather than New York's five-year moratorium, and its elimination of a fair price requirement post-moratorium. Namely, the ratio of five to three year moratorium statutes went from 7:2 prior to Delaware's action, to 6:3 in the year of Delaware's action, to $3: 10$ thereafter. ${ }^{64}$ Similarly, before the Delaware legislation, all business combination freeze states had a fair price requirement either as a component of the statute or integrated with a pre-existing fair price statute. But after Delaware pioneered the strategy of a business combination freeze statute with no fair price requirement, close to half of the states adopting a business combination freeze statute (ten of twenty-three) also chose to not include a fair price component, and of the states that included such a component, about half (six of thirteen) already had fair price statutes. This is another reversal of the prior lawmaking trend, since before Delaware acted only three of nine states adopting the New York package of a business combination freeze and fair price statute had preexisting fair price provisions.

60 See, e.g., ROMANO, supra note 6, at 96-98; ROBERTA ROMANo, THE GENIUS OF AMERICAN CORPORATE LAW 59-60 (1993); Romano, supra note 56.

61 The Delaware bar considered and rejected a control share acquisition statute after the CTS decision (corporate law reforms in Delaware originate with the state bar committee). See, e.g., Alva, supra note 5, at 904-09. Several months later, representatives of Boeing Corporation, the target of a hostile bid, sought legislative relief from Delaware state officials, and they were referred to the bar committee, as the source of all corporate legislation. Delaware adopted the business combination freeze statute several months after that referral, but the statute did not take the form that Boeing had proposed. Id. at 909-10.

62 It should be noted that Delaware was not the first state to reduce New York's five-year moratorium period to three years; two states (Arizona and Wisconsin) had previously done so.

63 DEL. CODE ANN. tit. 8, § 203 (2001).

64 The falling ratios do not include the impact on one of the states (Minnesota) that had enacted a five-year moratorium before the Delaware legislation, and reduced it to a four-year moratorium, one year after Delaware acted. 


\section{Figure 5: Diffusion of Business Combination Freeze Statutes}

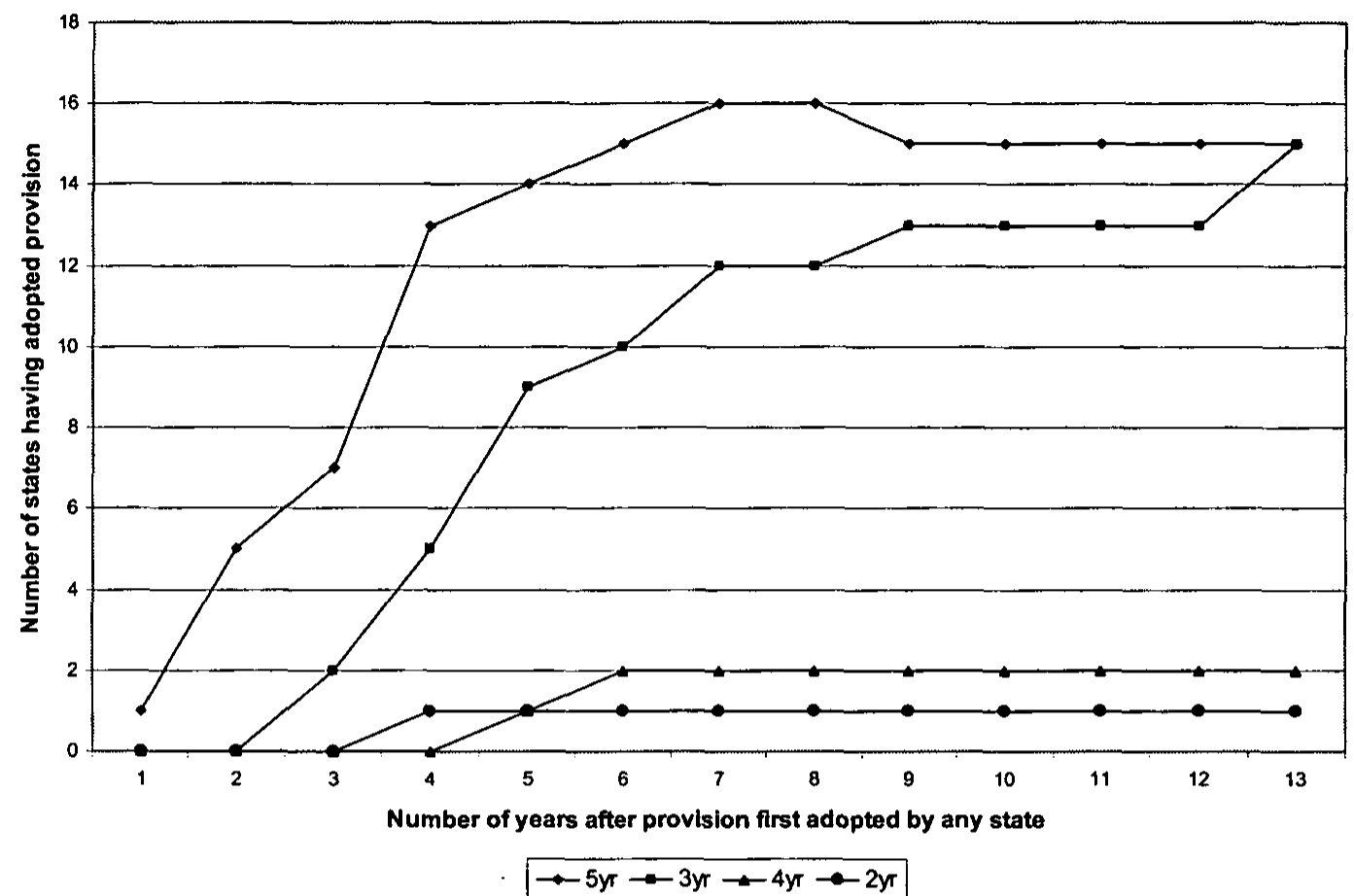

$5 \mathrm{yr}=$ Five year moratorium (15 states, first adoption 1985)

$3 \mathrm{yr}=$ Three year moratorium (15 states, first adoption 1987)

$4 \mathrm{yr}=$ Four year moratorium ( 2 states, first adoption 1989)

$2 \mathrm{yr}=$ Two year moratorium (1 state, first adoption 1988)

The third innovation in Delaware's statute that was less restrictive than the predecessor statutes, the exemption for hostile bidders acquiring $85 \%$, influenced other states, but to a lesser extent, and is therefore not plotted in a figure. Six of twenty-three post-Delaware enactors of a business combination freeze statute adopted such an out. Four copied Delaware's $85 \%$ exemption and the other two set the exemption at $90 \%$, which Delaware considered and rejected as a threshold too difficult to attain. ${ }^{65}$

65 The statutes with an $85 \%$ share purchase exemption are: 805 ILL. COMP. STAT. ANN. 5/11.75 (West 2004) (statute enacted 1989), IOWA CODE ANN., \$ 490.1110 (West 1999) (statute enacted 1997), OKLA. STAT.ANN. tit. 18, § 1090.3 (West 1999) (statute enacted 1991) and OR. REV. STAT. $\S$ 60.835 (2003) (statute enacted 1991). Those with a 90\% share purchase exemption are: GA. CODE ANN. $\S 14-2-1132$ (2003) (statute enacted 1988) and MASS. GEN. LAwS ANN. ch. 110F, § 1 (West 1999) (statute enacted 1989). The SEC is sometimes credited with the presence of the lower $85 \%$ threshold in the Delaware statute: the original draft had a $90 \%$ share purchase requirement, and SEC Commissioner Joseph Grundfest provided evidence to the Delaware legislature and bar, compiled by the agency's office of the chief economist, that indicated that for a substantial percentage of large public companies it 
While the rapid progress of takeover statutes across the states serves as a reminder that state competition need not be for the better, the data suggest that Delaware's leading role in charter competition still has a salutary effect, from the shareholders' perspective, on statutory experimentation. That is because Delaware's action appears to have had a dampening effect on restrictive takeover regulation, as several states followed its less constraining approach on different statutory dimensions. This effect-albeit less pronounced-parallels Delaware's impact on responses to the D \& O insurance crisis, in which most states followed its lead and left the decision limiting liability to firms' shareholders. Because states often use Delaware as the benchmark in drafting their codes, and far more public companies are incorporated in Delaware than elsewhere, the significance of its code provisions being decidedly less managerialist than other states' provisions is consequential and at odds with the assertion that Delaware's role in the making of corporation codes disadvantages shareholders.

Figure 4 also plots the progress of two additional takeover statutes-other constituency statutes and poison pill validation statutes-that have diffused throughout the states independently of the principal post-MITE experimentation among the control share acquisition statute and the variants of a fair price requirement. These two statutes, whose adoption took off after 1988, were not part of a post-MITE experimentation strategy because their constitutionality was never in question. They are not impositions of structural requirements on bids, but rather, instructions to courts, concerning the scope of review of management action to fend off an offer, a jurisprudential area the Supreme Court had expressly left to the states. ${ }^{66}$ As a consequence, other constituency and poison pill validation statutes have been adopted by a large number of states, but over a longer interval than the principal set of second-generation statutes, which went in and out of fashion as the constitutionality of state takeover regulation was being adjudicated. They also appear not to be perceived as adequate in and of themselves for protecting local firms from unwanted bids, because the vast majority of these statutes were adopted in conjunction with one of the other four patterns of second-generation statutes earlier discussed. Twenty-six of thirty-one other constituency and twenty-seven of twenty-eight poison pill validation statutes were adopted either simultaneously with, or after the state had enacted one of the other four secondgeneration statutes.

would be impossible for a bidder to obtain $90 \%$ of the shares. See, e.g., INVESTOR RESPONSIBILITY RESEARCH CTR., STATE TAKEOVER LAWS, at Delaware-6 (2004).

66 In Schreiber v. Burlington Northern, Inc., 472 U.S. 1 (1985), the Supreme Court held that defensive tactics were not "manipulative" conduct covered by the federal securities laws and hence their legality was left to state fiduciary duty law. In some states, legislatures adopted poison pill validation statutes after local courts invalidated the defense. The New York legislature, for example enacted a statute endorsing poison pills on December 21, 1988 in response to a July 1988 decision invalidating Irving Bank's pill, Bank of New York Co. v. Irving Bank Corp., 528 N.Y.S.2d 482 (Sup. Ct. 1988). See INVESTOR RESPONSIBILITY RESEARCH CTR., supra note 65, at 2. 
In Delaware, which has neither an other constituency nor a poison pill validation statute, the state supreme court has upheld poison pill defenses, rendering statutory validation unnecessary, while it has rejected the broad discretion accorded directors under other constituency statutes, by requiring any consideration of non-shareholder interests to provide a benefit to the shareholders, and by rejecting the propriety of such considerations in a takeover auction. ${ }^{67}$ Because many state courts follow Delaware decisions, it would seem that the strategy of legislatures enacting other constituency statutes was to preempt or constrain their state courts from following the Delaware court's approach. In contrast to the business combination freeze statute, in this instance, it is plausible to contend that Delaware's less restrictive approach to takeovers did not have a strong influence on other states. However, state courts still have considerable leeway to evaluate the discretion accorded boards under the statutes, and except for Connecticut, the statutes would appear to be little more than symbolic politics because they have no enforcement mechanism: Non-shareholder constituents have no standing to sue boards to require their interests to be considered in responding to a bid. ${ }^{68}$

The enactment of takeover statutes is problematic from the perspective of their potential to reduce the effectiveness of an important disciplinary device over managers: the market for corporate control. In assessing the output of the states in the takeover context, however, the key question from the standpoint of federalism is whether a national regulatory regime would be markedly different and for the better. There is good reason to believe that a national regime would be at best the same, and quite probably worse. First, federal takeover regulation had the same structure as first-generation takeover statutes, whose pioneer, Virginia, enacted legislation the same year that Congress did. Second, and more important, prior to the Supreme Court's clarification in CTS that the states still had a role in takeover regulation, numerous bills and hearings were held in Congress to legislate in the takeover area, and the pattern of activity replicated that of the states. The vast majority of proposed bills regulated bidders and permitted defenses, adopting the same strategy of state statutes, and there was a high degree of firm specificity in the source of legislative interest in that the proponents of bills and holders of hearings were often from states in which a target was fighting off a hostile bid. ${ }^{69}$ In addition, congressional activity, which had increased significantly after MITE, substantially declined after CTS. ${ }^{70}$

67 See, e.g., Revlon, Inc. v. MacAndrews \& Forbes Holdings, Inc., 506 A.2d 173 (Del. 1986) (invalidating defensive action that benefited bondholders); Moran v. Household Int'l, Inc., 500 A.2d 1346 (Del. 1985) (upholding poison pill).

68 The absence of an enforcement mechanism is consistent with event studies' failure to find systematic price effects for other constituency statutes, in contrast to the negative effects found for control share acquisition statutes. For a review of the event studies of state takeover statutes, see ROMANO, supra note 60 , at 60-67.

69 Romano, supra note 57 , at 470-74, 481-85.

$70 \quad I d$. at $479-81$. The most plausible explanation of why Congress did not enact further takeover regulation is that the states had taken care of the problem from the perspective of the advocates 
Moreover, the one bill that came out of a committee for debate on the chamber floor after CTS had a provision explicitly upholding state regulatory authority over takeovers. ${ }^{71}$ This pattern of activity suggests that, had the Supreme Court ruled otherwise, Congress would most likely have enacted takeover regulation that mimicked the states' second-generation statutes.

Finally, there is the potential for greater restrictions on takeovers in a national regime than in the present regime of state regulation. Under a national regulatory regime, there is no safety valve, as exists in the laboratory of the states, whereby firms can choose among states with restrictive laws, Delaware's more bidder-friendly regime, and states with no takeover statutes at all. Delaware's incentive to obtain chartering revenue results in a distinctive political process, in which it produces more flexible takeover statutes than the typical state choosing to regulate bids, and correspondingly, influences other states to follow its lead and enact less restrictive laws. With no similar incentive operating at the national level, the most educated guess regarding the legislative output is that Congress's takeover regulation would replicate at best, the average state's regime, which is more restrictive than Delaware's. Yet under such a national corporation code, firms would not have the option to choose a regime less restrictive than the average, and hence more satisfactory from shareholders' perspective.

\section{B. Role of the Model Business Corporation Act}

An important contributing factor to the diffusion process of corporate law is the activity of the bar in devising and revising a model statute, the Model Business Corporation Act. States can follow the Model Act in place of, or in addition to, looking to Delaware. The Model Act is a product of the Committee on Corporate Laws of the American Bar Association's (ABA) Corporate and Business Law Section, whose members are generally attorneys in large firms whose clients are public corporations. ${ }^{72}$ The first Model Act was produced in 1950, and there have been several major revisions, most prominently in 1969 and 1984, although incremental changes have been made after each revision. ${ }^{73}$

of restrictive legislation and not that members of Congress preferred not to regulate hostile transactions, given their activity prior to the CTS decision and the far longer historical reaction time at the federal level between legislative responses to judicial decisions, than at the state level. See supra notes $42-43$ and accompanying discussion.

71 See S. 1323, 100th Cong. $\$ 36$ (1987); 134 CONG. REC. 14,611-27 (1988) (start of debate over S.1323); 133 CONG. REC. 15,120-21 (1987) (introduction of S. 1323 by Senator Proxmire). The only variance in the bill from state law on the permissibility of firm-level defenses was that it would have required a shareholder vote to adopt a poison pill during a takeover contest.

72 Camey, supra note 20 , at 725.

73 See id. The ABA Corporate Law Committee took on the task of drafting a national corporation law in 1940, and upon completing a draft in 1943 turned to drafting a model act for state use, which was published in 1946; the 1950 revision of that draft statute is now considered the first Model Act. Melvin Aron Eisenberg, The Model Business Corporation Act and the Model Business Corporation Act Annotated, 29 BUS. LAw. 1407, 1407-08 (1974). The Illinois statute provided the basis 
States may follow the Model Act closely, but a state may also modify provisions in the Model Act or adopt only parts of it. Indeed, some state codes are an amalgam of provisions in the Model Act, the Delaware statute, and other states' codes as well. ${ }^{74}$ This affects the diffusion process, for states differ in the speed with which they respond to changes in the Model Act, depending on whether they adopt amendments to the Model Act piecemeal or through complete recodifications. In addition, as mentioned, there is some variance across states regarding which provisions of the Model Act are adopted. ${ }^{75}$ As earlier noted, the drafters currently count thirty-two states as having corporation statutes based on either the 1969 or 1984 Model Act revisions. ${ }^{76}$

The Model Act is a source of statutory innovation, but the degree of originality of Model Act provisions varies considerably. Sometimes the Model Act drafters copy Delaware's innovations or those of other states, and sometimes in doing so they modify the innovation in response to problems identified ex-post in implementation. At other times, they are indeed the innovators. ${ }^{77}$ The state-wide pattern of adoption of the four provisions previously identified with the 1967 modernization of the Delaware code, which were not in the Model Act at the time, suggests that even though the Model Act was not the first to adopt the initiatives, it influenced their diffusion. This is not the case with regard to the states' rapid legislative response to the $\mathrm{D} \& \mathrm{O}$ insurance crisis of the 1980 s, or takeover regulation.

for the Act because the principal drafters on the ABA committee were from Illinois. See Ray Garrett, History, Purpose and Summary of the Model Business Corporation Act, 6 BUS. LAW. 1,1 (1950-51).

74 For example, annotations to provisions in the New Jersey statute refer to sources in the Model Act, California, Delaware and New York state statutes. See e.g., N.J. STAT. ANN. § 14A:3-5 Commissioners' cmts. (West 2003) (on "Indemnification of directors, officers and employees," noting section derived from New York law and other section from Model Act); id. § 14A:6-1 (on "Board of directors," noting section derived from Delaware law and other section from Model Act); id. § 14A:6-8 (on "Director conflicts of interest," noting provision adapted from California). Annotations to provisions in the Texas statute refer to sources in the statutes of Illinois, Ohio, Oklahoma and New York, among others, as well as the Model Act. See, e.g., bar committee sources listed in the 1980 main volume (replaced in 2003), available in Westlaw TX-STANN02 library, to TEX. BUS. CORP. ACT, arts. 2.32 ("Number and Election of Directors," derived from Model Act, Delaware, Illinois, and Ohio corporation statutes), 4.04 ("Articles of Amendment," subsection A(2) derived from the New York Stock Corporation Law and the rest from the Model Act), 4.08 ("Procedure for Redemption," derived from Oklahoma law with no comparable provision in Model Act).

75 For information on when various states have adopted model act provisions, and how many states have particular provisions, see Carney, supra note 20. The MODEL BUS. CORP. ACT ANN. (2005) provides, for each section, a comparison of all state statutes.

76 MODEL BUS. CORP. ACT ANN. intro. at xxvii (2005).

77 For some innovations by the Model Act drafters see Carney, supra note 20, at 747-48. As noted in the text, the limited liability provision in the Model Act was a response to Delaware's innovation. 


\section{The Model Act and the 1967 Delaware Code Modernization}

Of the tracked provisions related to Delaware's 1967 code modernization, the initiatives limiting appraisal rights ${ }^{78}$ and clarifying indemnification rights appeared for the first time in the 1969 revision of the Model Act. By contrast, a merger vote exemption was first included in the 1984 revision, and nonunanimous shareholder action without a meeting still is not provided for in the Model Act. The indemnification initiative was, in fact, a joint product of the ABA Corporate Laws Committee and the Delaware Corporate Law Revision Committee, which was created in 1963 by the state legislature to undertake a comprehensive review of the state's corporation law and drafted the 1967 revised code. As a consequence, the language of the Delaware and Model Act revised indemnification provisions was substantially identical. ${ }^{79}$

Although not all states mentioned the Model Act as the source of indemnification provisions that tracked the Delaware and Model Act provision in their official statutory comments or annotations, it is plausible to assert that the Model Act's influence on adoption was greater than Delaware's because enactments accelerated only after the Model Act revision was published, and not immediately following Delaware's legislation. The diffusion pattern of the other three provisions provides further support for the view that the Model Act influenced the diffusion of the Delaware 1967 reform initiatives. Most of the state adoptions of the two provisions related to Delaware's 1967 code modernization that were included in the 1969 Model Act revision-appraisal rights exemption and indemnification clarification-occurred after 1969 and not after Delaware's action in $1967 .^{80}$ The 1967 initiative absent from the Model Act-nonunanimous shareholder action without a meeting-had few adoptions through the endpoint of the collection of the data in Table 1 (1975). Still, Delaware did influence other states. Today the number of states permitting nonunanimous shareholder action without a meeting stands at twenty-four, despite the absence of such a provision in the Model Act. ${ }^{81}$

In addition, somewhat fewer states adopted the merger vote exemption compared to the appraisal exemption in the period before the Model Act was revised to include the merger vote exemption (twenty-two compared to twenty-

78 The appraisal rights exemption for publicly traded firms that was included in the 1969 Model Act revision was eliminated in the 1978 amendments to the Act, but was reintroduced in 1999. MODEL BUS. CORP. ACT ANN. $\S 13.02$ hist. n. at 13-29 (2005).

79 MODEL BUS. CORP. ACT ANN. $\$ 8.50$ hist. n. 16 at 8-291 (2005). It should be noted that the indemnification provision in the original 1950 Model Act was modeled on the provision in Delaware's code at that time, which was selected for its "brevity and simplicity," and was the type found in most state statutes; given its generality, it obviated the need for a specific charter or bylaw provision. MODEL BUS. CORP. ACT ANN. $\S 5$, cmt. at 218 (2d ed. 1971).

80 It should also be noted that about the same number of states adopted the provisions between 1967 and 1969 (that is, following Delaware), as did so in 1969 (the Model Act revision was published by the ABA by mid-year).

81 MOdEL BUS. CORP. ACT ANN. $§ 7.04 \mathrm{cmt}$. at 7-38 to 7-39 (2005). 
six states). Currently, however, the totals are thirty-seven and thirty-two states, respectively. That differential provides further evidence of the Model Act's impact on the diffusion process, because the appraisal exemption was removed from the Model Act during this time frame, and the relative rate of its adoption slowed compared to the merger vote exemption provision that was added to the Model Act in the same interval. These data suggest a more subtle role for Delaware's influence on the diffusion process: The Model Act drafters in all probability added the merger vote exemption provision and reintroduced the appraisal exemption provision because they appeared in Delaware's code and had been adopted by a number of states.

The import of the Model Act is more ambiguous regarding the longerstanding initiatives on cumulative voting and staggered boards. The Model Act was revised to take a permissive approach to cumulative voting in $1955 ;^{82}$ sixteen states already had such a code provision at that time, and five years later, by 1960 , only four more had followed its lead. While the number of states that moved to permit, rather than require, cumulative voting nearly doubled by 1981 , to the extent that those states were affected by the Model Act, it cannot be considered a rapid-inducing agent of change (today only eight states still mandate cumulative voting). There is even more attenuation in impact regarding staggered boards. A provision permitting board classification was included in the first Model Act of 1950, at which time thirty-three states already had an analogous provision in their corporation codes. In the decade following, only two more states adopted such a provision and the number was at forty in 1968, the year before the Model Act was revised (today all fifty states permit staggered boards). It is therefore difficult to attribute the post1960 increase to states' adoption of the revised Model Act.

2. The Model Act and 1980s Initiatives Limiting Director Liability and Regulating Takeovers

In contrast with its relation to the 1967 Delaware code initiatives, the Model Act was not a factor in the diffusion of the limited liability reform initiative. A limited liability charter amendment provision was not included in the Model Act until 1990, despite the enactments of the Delaware and Indiana alternatives in 1986, and a damages cap in Virginia in $1987 .{ }^{83}$ The majority of states did not, however, wait for guidance from the Model Act to respond to the issue. Thirty-six states had already adopted the Delaware approach before the

82 MODEL BUS. CORP. ACT ANN. 522 (1960); Eisenberg, supra note 73, at 1414. It should be noted that because many states had constitutional provisions requiring cumulative voting, this reform was more difficult to implement than other corporate law revisions that replaced statutes.

83 The Model Act provision refined the language of the statutory exceptions in the Delaware statute, and permitted application to inside as well as outside directors. See Committee on Corporate Laws, supra note 37. The inclusion of officers was not an innovation of the Model Act: Several states had already done so, including Louisiana, Maryland, and Nevada. See Hanks, supra note 27, at 1210-11. 
Model Act was amended, twenty-one of which were Model Act states, while only nine states did so thereafter. ${ }^{84}$ Moreover, all but one of the states enacting one of the other statutory responses to the $\mathrm{D} \& \mathrm{O}$ insurance crisis before the Model Act was revised in 1990 were Model Act states.

The Model Act contains no takeover statutes. Consequently, when such provisions are included in state codes, there is often an official comment indicating that there is no analogue in the Model Act. The intensive legislative activity regarding takeover regulation, that completely ignores the posture of the Model Act, parallels the states' reaction to the D \& $\mathrm{O}$ insurance crisis. Taken together, the diffusion of these two types of statutes would suggest either that the relative importance of the Model Act as a template for state codes dramatically declined in the 1980 s from earlier decades, or that the impact of the Model Act on the diffusion process is minimal when business conditions lead the relevant local interest groups and elites-managers or the corporate bar-to press vigorously for legislative action. ${ }^{85}$

The absence of a takeover statute in the Model Act appears to have had some beneficial influence, to the extent that, as many commentators contend, the presence of such statutes harms shareholders. Of the seven states with no second-generation takeover statute, five were Model Act states during the peak years of hostile takeovers and consequent state legislative reactions. ${ }^{86}$ This translates into a larger proportion of Model Act states having no such takeover regulation compared to non-Model Act states (17\% compared to $10 \%){ }^{87}$ However, the reason why these states have no takeover statutes is, most plausibly, not because the state legislatures are following the Model Act's lead on the issue and are more shareholder-oriented than other states' legislatures, but because they have a very small number of local public corporations. Those

84 Of those nine states, six are currently identified as Model Act states but one, Maine, cannot be said to have been affected by the 1990 Model Act revision because it had enacted an Indiana-style culpability statute in 1988 and its adoption of a limited liability charter amendment provision in addition to that statute was in 2002, more than a decade later. In addition, all but one of the states that enacted the alternative of a relaxed culpability statute are currently identified as Model Act states, and those states did not repeal their culpability provisions when the Model Act took a different (the Delaware) tack.

85 Carney interprets the more rapid diffusion of takeover and limited liability statutes across the states, compared to the 1967 reform initiatives, as due to their sponsorship by corporate managers (compared to the corporate bar), whom he considers better organized politically because of a greater personal interest in the issues; but he notes that he cannot rule out as an alternative explanation the possibility that technological change has accelerated the spread of information across the states in the 1980s. Carney, supra note 20, at 736-55, 749.

86 The states without takeover statutes are: Alabama, Alaska, Arkansas, California, Montana, New Hampshire and West Virginia. California is not a Model Act state and West Virginia adopted the Model Act in 2002, long after takeover statutes were enacted across the states. See MODEL BUS. CORP. ACT ANN. intro. at xxvii (2005); David K. Higgins et al., 2002 Changes to the West Virginia Corporate Law, W. VA. LAW., Aug. 2003, at 18.

87 Delaware's influence on takeover regulation is uncorrelated with Model Act status. Of the states with business combination freeze statutes that are patterned after Delaware (no parallel fair price provisions), five are Model Act states and four are not. In addition, four of those Model Act states, and three of the non-Model Act states, also have either a control share acquisition or redemption rights statute, and thus they are all more restrictive of bids than Delaware. 
five states had a total of sixteen domestically-incorporated local corporations in 1999, according to domicile classifications by Lucian Bebchuk and Alma Cohen. ${ }^{88}$ In such circumstances, not only is it not worth the local bar's time and effort to draft a more specialized state statute as opposed to adopting the ABA's off-the-shelf corporation code, but also, there is limited local demand for a takeover statute. There are so few local publicly-traded firms that it is most probable that none had a need for protective legislation.

One means of evaluating whether the difference between the diffusion pattern of the 1967 initiatives and the limited liability and takeover statutes in the 1980s reflects a new and permanent change in the influence of the Model Act is to examine the diffusion of more recent initiatives that would not have been of intense interest to managers. In an important study of the impact of the Model Act on the diffusion of corporate law reforms, William Carney identified a subset of provisions of recent origin related to organizational flexibility, introduced by either Delaware or the Model Act, that meet those requirements. ${ }^{89}$ Figure 6 updates his data for two of those provisions, a 1990 innovation of Delaware that permitted electronic proxy voting, and an innovation in the 1984 revised Model Act that established plurality (nonmajority) shareholder voting on matters other than the election of directors. ${ }^{90}$ Both of these initiatives are efforts at facilitating institutional flexibility in the shareholder voting process, and the effect of managerial lobbying does not appear to have been a factor in their adoption. In 1996, the Model Act was revised, paralleling the Delaware statute, to permit electronic proxy voting.

88 Their dataset consists of 6530 publicly traded firms identified from the 1999 Compustat database, a database with information from the financial statements of over 24,000 active and inactive public U.S. and Canadian firms. Lucian Arye Bebchuk \& Alma Cohen, Firms' Decisions Where To Incorporate, 46 J.L. \& ECON. 383, 392-93 tbl. 3 (2003). Four more firms were incorporated but not physically located in those five states. By contrast, the twenty-five Model Act states with takeover statutes had 681 local incorporations (836 corporations). Id. One of those states had fewer incorporations than the five states with no takeover statutes and another six had about the same number (between three and six local incorporations).

89 Carney, supra note 20 , at 744-49. Camey was interested in testing a hypothesis slightly different from that in this article, which his data confirmed: that Model Act initiatives would be more widely adopted than initiatives of a single state.

90 Carney examined two Delaware, one North Carolina, and four Model Act innovations. I do not include the other Delaware innovation in Carney's comparison, which related to mergers, since an appropriate comparison for my purpose requires minimizing the possibility of selection effects-that is, I need a provision that could be of use to all firms, so that all states could be motivated to adopt it-and in my prior research on firms' domicile changes, I found that Delaware was favored by firms planning to engage in mergers. Romano, supra note 5. I also use only one Model Act initiative of the four that Carney examined, the one closest to the subject of the Delaware initiative, to facilitate a comparison of relative influence: both had similar organizational benefits, improving the efficiency of the voting process by facilitating the accomplishment of a quorum. MODEL BUS. CORP. ACT ANN. $\$ 7.25 \mathrm{cmt}$. n.4 (2005); Carney, supra note 20, at 745-46. It should be noted that Delaware was not actually the pioneer for electronic proxy voting. New Jersey permitted electronic transmissions of proxy votes in 1988. At the time of Carney's study, the Delaware initiative had not been adopted by many states, but he correctly anticipated a future increase because the Model Act had just been amended in 1996 to permit electronic voting. The Model Act initiative on plurality voting had more adoptions then, although it was still low for a Model Act provision, in that fewer than half of the states had adopted it. 
Delaware has never adopted plurality voting for shareholder action apart from the election of directors, and instead retains majority voting, which was the approach of the 1969 Model Act.

As Figure 6 shows, all but four states now have adopted an electronic proxy voting provision, with the bulk of the adoptions coming a few years after the provision's inclusion in the Model Act. Thus, the Model Act's impact here appears to be similar to its relation to the 1967 Delaware initiatives. While not the innovator, it seems to be a catalyst of legislative action. That is, more state codes were modified after the initiative was included in the Model Act. This suggests that the limited liability and takeover statutes are distinctive statutory settings, and the Model Act's function as a transmission belt for innovations that enhance organizational flexibility and have no self-evident shareholdermanager conflict has remained relatively intact up to the present. It should be noted that the diffusion process across the states themselves, however, does not significantly differ over time and hence substantive content, despite the Model Act's varying influence, with respect to which states are more responsive. There is a statistically significant positive association in the ranking of the states in the order of when they enacted the initiatives on indemnification clarification, limited liability and electronic proxy voting. ${ }^{91}$

Of course, this pattern is only suggestive, and not conclusive of the Model Act's influence. Because over time there should be an increase in the number of states adopting a provision that is of value to firms, the source of the upswing in the electronic proxy statute adoptions may simply be the passage of time, rather than the Model Act's endorsement. ${ }^{92}$ But the facts are not consistent with such a hypothesis. The number of states adopting plurality voting has steadily increased over time, rising to a majority, but it is still far less than the number adopting electronic proxy voting (only thirty-one states compared to forty-six) and the time period over which the diffusion of plurality voting has taken place is over a decade longer. This suggests that more than time or the Model Act is necessary to explain a provision's adoption by an increasing number of states. The substantive content in conjunction with the presence of a viable alternative may well matter. In the context of plurality voting, the non-adopting states all

91 A statistical measure for determining the consistency (correlation) in multiple rankings is the Kendall coefficient of concordance. See, e.g., SIDNEY SIEGEL \& N. JOHN CASTELlan, JR., NONPARAMETRIC STATISTICS FOR THE BEHAVIORAL SCIENCES 262 (2d ed. 1988). The value for the states' rankings (from first to last to adopt a provision) for those three statutes is .5037 , and it is significant at less than $1 \%$ (chi-square value of 74). The positive ranking holds up when second generation takeover statutes are included as well, although the correlation is smaller (.4545), it is equally statistically significant at less than 1\% (chi-square of 89). I used one provision from the 1967 modernization for this computation because my earlier study found that the states' rankings for responsiveness across all of those statutes, as well as first generation takeover statutes, was consistent (the Kendall coefficient of concordance was significantly positive at less than 1\%). See Romano, supra note 5 , at 238 .

92 I have not tested whether the observed pattern is not random as an indication of the Model Act's influence, because the appropriate benchmark for such a test would be to compare the pattern to a formal model predicting when a state would adopt a provision in the absence of the Model Act. 
follow the same approach to shareholder voting as that followed by Delaware, which was also the approach of the 1969 Model Act. ${ }^{93}$ In my judgment, the differing adoption patterns of these two voting initiatives provide evidence of a "states as laboratory" effect. While there are some "Model Act" states that adopt Model Act revisions in entirety, the many non-Model Act states appear to pick and choose from alternative approaches. Thus the Model Act's interaction with the Delaware statute, sometimes in tune, sometimes out of tune, contributes to experimentation and innovation in corporate law.

Figure 6: Diffusion Process: Recent Delaware and Model Act Innovations

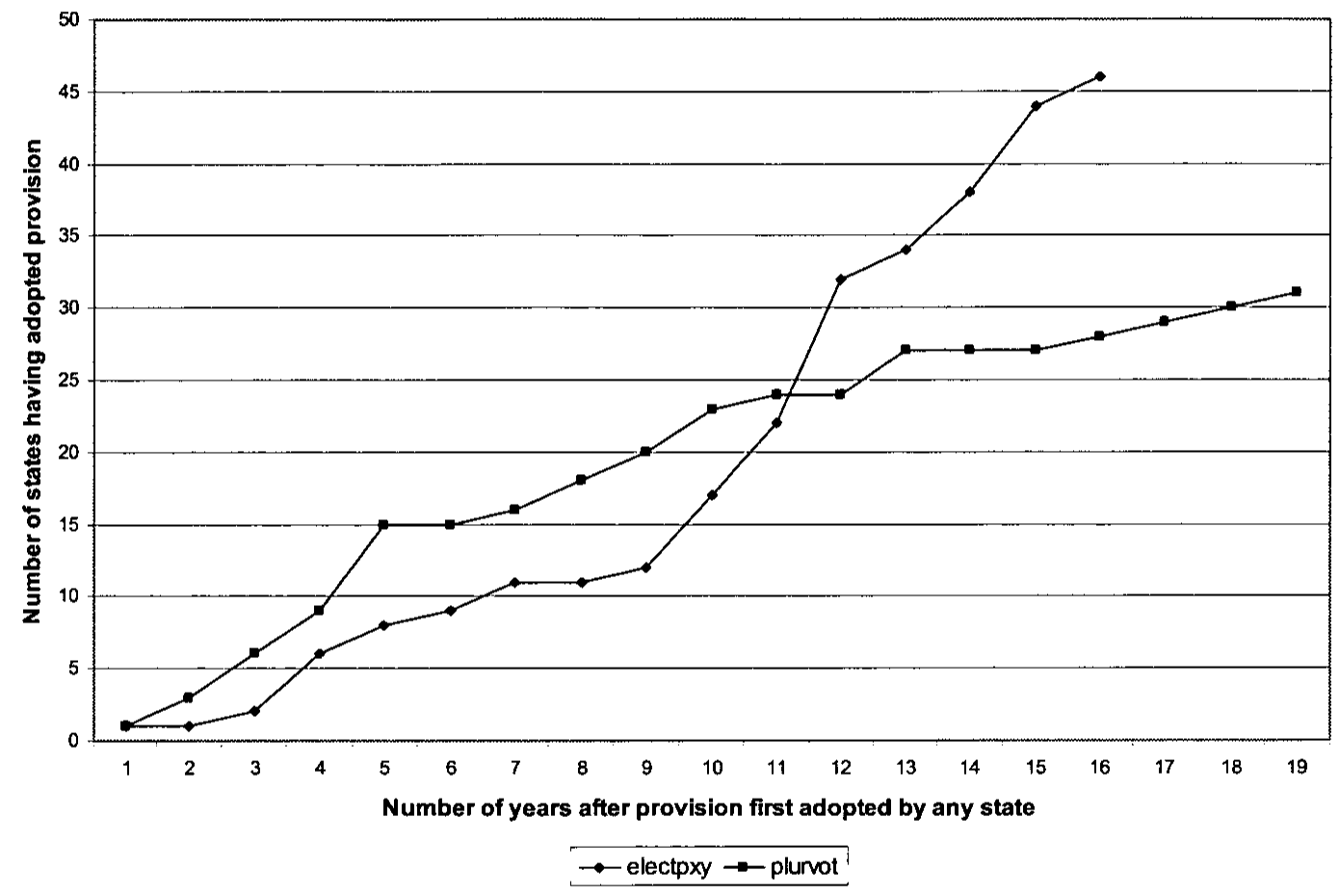

Electpxy = Electronic Proxy Voting (46 states, first adoption 1988; includes Texas statute adopted in 2003, although effective date is 2006)

Plurvot $=$ Plurality Voting (31 states, first adoption 1985)

Additional support for the laboratory interpretation of the effect of the Model Act can be drawn from further data in Carney's study. Carney examined the diffusion of 142 provisions of the Model Act and found that thirty of those provisions had not been widely adopted; that is, they were adopted by twenty-

93 Although the language in three state statutes, "majority of votes cast", could be considered equivalent in effect to plurality voting if abstentions are not construed to be "cast" votes, this does not appear to be the common interpretation, because the Model Act drafters stated that there was no counterpart in any state code to the Model Act provision when it was introduced. MODEL BUS. CORP. ACT ANN. $\$ 7.25$ hist. n.2 (2005). 
five states or less. ${ }^{94}$ Carney separately examined those provisions to ascertain whether the variation in corporation codes at a given point in time is due to the fact that reforms diffuse across the states slowly, with uniformity being the end product. He concluded that the data were consistent with the view that the limited level of adoption across the states of those thirty provisions was related to their relative newness, because twenty-seven of them were introduced in the 1984 revision of the Model Act or later. ${ }^{95}$ Another explanation for the variation could be related to the content of Delaware's corporation code and the laboratory explanation of Model Act diffusion. Namely, to the extent that Delaware's approach is at odds with that of the Model Act, there could be variation across the states that is not simply due to differential rates of code modernization. Rather, states might not copy the Model Act so that they may opt for what they consider to be a preferable alternative, such as that found in Delaware's code.

To determine the plausibility of the alternative explanation, I checked whether the thirty Model Act provisions that Carney found had not been widely adopted were present in Delaware's code. Delaware had, in fact, no analogous provision for twenty-five of the thirty provisions. ${ }^{96}$ The absence of most of these provisions from Delaware's code is consistent with the conjecture that their absence from many other states' codes is not solely a matter of timing. Those states could have opted for an alternative approach (Delaware's) to the Model Act.

While the current count of states with provisions replicating the thirty Model Act provisions is higher by a few more states than the count in Carney's study, most of the provisions are still found in fewer than twenty-six state codes. Three of the seven provisions now in more than twenty-five state codes also appear in Delaware's code, a circumstance where the laboratory, or competing legal regimes explanation is inapplicable. ${ }^{97}$ One must, however, be cautious when undertaking such a comparison. Delaware may not have a statute identical to a Model Act provision because the subject has already been

94 The thirty provisions are identified in Table 5. Carney, supra note 20, at 774-76.

95 More specifically, Carney based his conclusion on the fact that when the twenty-seven newer provisions were deleted from his set of provisions, there was a higher degree of uniformity for the remaining provisions (enacted in $77 \%$, rather than $74 \%$, of the states). Id. at 734 .

96 I checked both the Delaware statute and the statutory comparison sections in the MODEL BUS. CORP. ACT ANN. (2005) for this inquiry. In a few instances, the comparisons in the official annotation to the Model Act stated that there were no analogous provisions in the Delaware code but there were actually similar provisions. For example, two of these instances involved provisions fixing distribution record dates, which are part of a larger legal capital scheme in the Model Act that has no counterpart in Delaware's code. Because that larger scheme was the basis for the official statutory comparison, Delaware was reported as lacking the provisions, although it actually has record date provisions with similar effect; they are just not related to any legal capital provisions.

97 I took on face value the counts of adopters that are provided in the official statutory comparisons sections in the MODEL BUS. CORP. ACT ANN. (2005), although a count is not provided for all provisions. The few provisions where the current count for adopters was lower than Carney's count were provisions that had been eliminated from the Model Act since Carney wrote his article but whose presence in state codes was still tracked in the statutory comparisons. 
adjudicated by its courts. In fact, Model Act provisions quite often codify Delaware judicial opinions, as the Model Act is of greatest value as a template for states in which there are not a sufficient number of firms for issues to be adjudicated by courts. ${ }^{98}$ But there is another datum lending plausibility to the laboratory interpretation that non-widespread adoption suggests a difference in Delaware's approach: Five of the thirty provisions have been eliminated from the Model Act since the Carney study, and none of the eliminated provisions were in Delaware's code. The failure of many states to have copied the Model Act version of those provisions would not appear to be related to the timing of code updating, because many of the states had codes in sync with that of Delaware. The differential numbers of adopters and non-adopters may well have been a contributing factor toward the Model Act's elimination of those provisions. Namely, the Model Act drafters may have gleaned from those "experiments" that firms preferred the Delaware code's approach, and updated the Act accordingly.

In sum, the Model Act is a conduit through which innovations in corporate law are introduced and transmitted across the states. Because Model Act initiatives are often reactions to initiatives undertaken by Delaware and other states, the Act functions more often as a catalyst of transmission than of innovation. Between twenty-five and thirty states use the Model Act as a screen for code updating, as it brings to their local bar and legislature's attention recent statutes devised by more innovative states or the ABA committee. In this regard, the Model Act appears to have greater influence on the diffusion of corporate law reforms than Delaware alone, which seems primarily to affect the diffusion process by spurring revisions to the Model Act. But the import of the Model Act needs to be placed in a larger context, the structure of the chartering market. Because more publicly traded firms are incorporated in Delaware than in all of the Model Act states put together, ${ }^{99}$ Delaware is, without doubt, by far the most important actor in the making of corporate law.

98 See Michael P. Dooley \& Michael D. Goldman, Some Comparisons Between the Model Business Corporation Act and the Delaware General Corporation Law, 56 BUS. LAW. 737 (2001). While this is clearly true for a few provisions-such as the Model Act provision that officers owe a duty of good faith and care (adopted by thirty states, MODEL BUS. CORP. ACT ANN. $\S 8.42$ hist. n. (2005))-I did not research whether this is true for others, such as the provision mandating notice to exercise cumulative voting rights. But for six provisions there is explicit statutory language in Delaware's statute at odds with the Model Act language, not counting the Model Act provisions with which the Delaware code differed and that were eliminated after the publication of the Carney study. It should also be noted that the count in the text of only five of the thirty Model Act provisions as in the Delaware corporation statute does not include provisions for which the Model Act annotation notes an equivalent Delaware judicial decision.

99 Bebchuk \& Cohen, supra note 88, at 391 (in 1998, over a majority-3771 - of a sample of 6530 firms in the Compustat database were incorporated in Delaware); Daines, supra note 5, at 1571 (more than a majority of IPO firms incorporated in Delaware); Romano, supra note 5 (half of largest firms incorporated in Delaware). The three states with the next largest numbers of incorporations after Delaware (and the only other states with over 200 domestic incorporations) in Bebchuk and Cohen's sample, California, New York and Nevada, are also not Model Act states. 


\section{Conclusion}

This Article has examined the diffusion of corporate law reform initiatives across the states over the past several decades. One observes a typical pattern of initial experimental variation regarding the statutory form thought to be best suited for handling a particular problem, followed by a majority of states eventually settling upon one format. This process ultimately results in relative uniformity across the states. Moreover, the leading domicile state, Delaware, has strong incentives to innovate to maintain its preeminent market position, and it has, indeed, been a consistent innovator in the diffusion process. An additional contributing factor to the diffusion process has been the activity of the national bar association in producing and publicizing a statutory template, the Model Business Corporation Act, which has often incorporated Delaware's solutions to problems.

In the past two decades, the diffusion process has been extremely rapid, with code changes transmitted across a majority of states in only a few years. This may be due, at least in part, to the personal interest of corporate managers in particular initiatives such as restricting takeovers and limiting liability. But in the takeover context there are several significant differences in the diffusion process compared to that of other statutes. Delaware is a laggard, and states have adopted multiple statutes, making codes less uniform on this regulatory dimension. The statutory diversity, which originated in uncertainty regarding the statutes' constitutionality, is often connected to legislatures' efforts to protect specific local firms from a hostile takeover. This is also a reason for Delaware's distinctiveness: Because the state provides a statutory, rather than physical, domicile, target managers cannot align with organized labor as effectively as they can in other states to prod the Delaware legislature to restrict bids to obtain the potential benefit of saving local jobs. In addition, Delaware has not been a leader in the takeover context because takeover regulation is considered questionable from the perspective of maximizing firm value, which is a key objective for Delaware's legislation, as it is an important ingredient for its successful chartering business.

The dynamic production of corporation laws exemplifies how federalism's delegation of a body of law to the states can create an effective laboratory for experimentation and innovation. How transferable this success is to other areas of law depends on whether the states would have incentives to get things right, as they do in the corporate chartering context where there is a 


\section{Legal Innovation and State Competition for Corporate Charters}

direct financial connection: Innovation enhances revenues from charter fees and the local corporate bar's income from servicing local clients. ${ }^{100}$

100 As earlier noted, evidence connecting legal innovation with chartering revenues and with reincorporations and retention of local incorporations is provided in Romano, supra note 5, at 236-42, 246-47, and Moodie, supra note 13. For a discussion of the financial incentives of states to compete for charters, see Roberta Romano, Is Regulatory Competition a Problem or Irrelevant for Corporate Governance?, 21 OXFORD REV. ECON. POL'Y 212, 218-23 (2005).

This Article does not have the space to detail how the product of this ongoing innovative process has improved social welfare by maximizing firm value. I refer the reader instead to other work collecting the evidence that supports this proposition. See, e.g., ROMANO, supra note 6, at 64-83. 
HeinOnline -- 23 Yal J. on Reg. 2482006 